Portland State University

PDXScholar

1972

\title{
Euryhelmis cotti N. Sp. (Trematoda: Heterophyidae) with observations on its life cycle
}

Michael Joseph Simon

Portland State University

Follow this and additional works at: https://pdxscholar.library.pdx.edu/open_access_etds

Part of the Bacteriology Commons, Environmental Microbiology and Microbial Ecology Commons, and the Pathogenic Microbiology Commons

Let us know how access to this document benefits you.

\section{Recommended Citation}

Simon, Michael Joseph, "Euryhelmis cotti N. Sp. (Trematoda: Heterophyidae) with observations on its life cycle" (1972). Dissertations and Theses. Paper 960.

https://doi.org/10.15760/etd.960

This Thesis is brought to you for free and open access. It has been accepted for inclusion in Dissertations and Theses by an authorized administrator of PDXScholar. Please contact us if we can make this document more accessible: pdxscholar@pdx.edu. 
11 LBSTRACT OF THE THESIS OF Michael Joseph Simon for the Master of Seience in Blology presented March 31, 1972.

It1e: Euryhelmis Cott1 N. Sp. (Trematoda: Heterophyldee) with Observations on Its Iffe Cycle.

IPPROVDD BI MPMBERS OF TEE THESIS COMMTIEE:

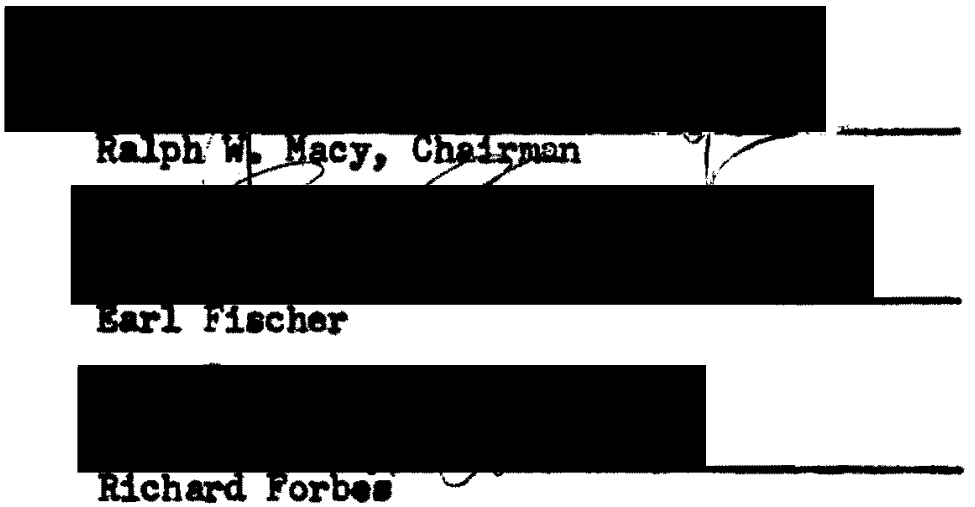

If in of the genus Cottus were found infected with heterophold motacorcariac. Laboratory animals were infected with the motacercarias, and adult beterophyld trematodes were recovered. These Flukes were found to represent an undescribed species of the genus Eurghelents. Var1ous streams in the W1Ilamette Valley and coastal areas were anpled for infected Cottus ap. Snailo of the genera Oxytrema and Funinicola were collected. Several possiblo definitive hosto wre exuatned. A partial review of the oubfandly Apophallinae and a complote roviev of the genus Euryhelmis are presented. Euryhelofie cott1 a. op. is placed in the subfamly Apophallinge, and ita 11fe ejele is partially described. 
EURTHELMIS COTTI R. SP. (TREMATODA: HETEROPHYIDAE)

WITH OBSERVATIONS ON ITS LIFE CICLB

by
MICHARL JOSEPH STYON

1 thesis submitted in partial fulfillment of the requiremente for the degree of

\author{
MASTER OF SCIENCE \\ in \\ BIOLOGI
}

Portland State University

1972 
TO THE OPFICE OF GRADUATE STUDIES

The nombers of the Conmittee approve the thesis of Hichael Joseph Simon presented March 31,1972.

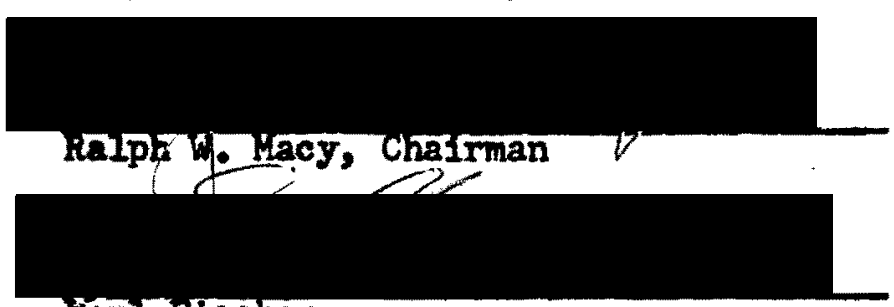

Barl lischer

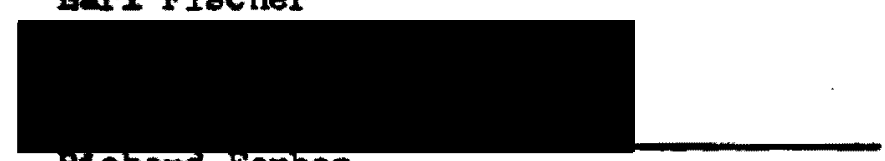

Richard rorbes

\section{APRROVED,}

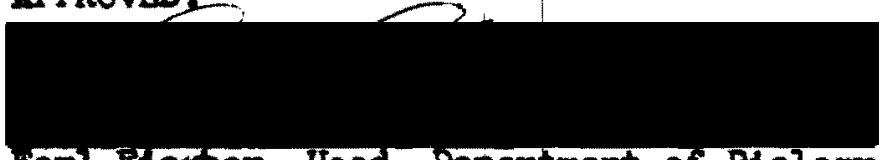

Garl Flocher, Head, Department of Blology

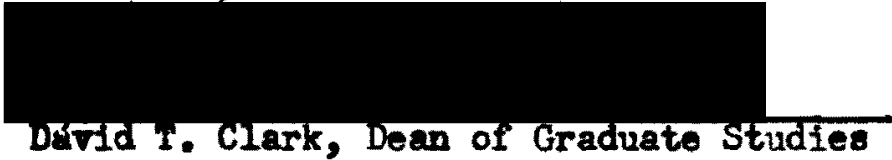


TABLE OF CONTENTS

PAOE

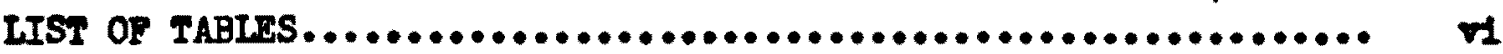

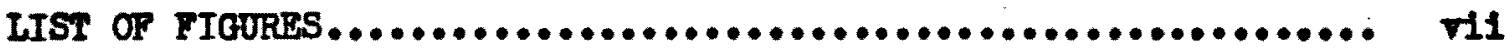

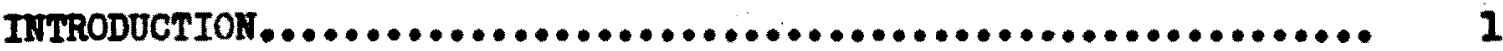
- METRODS

Collecting flsh and snalls........................ 8

Transporting fish and snails from the fleld to the

Iaboratory....................................... 8

Maintaining animals in the laboratory..................... 8

Obtaining metacorcariae............................ 9

Infectịg laboratory animals........................ 9

Excystation of metacercariae........................ 11

Examining snails for cercarlas....................... II RESULTS

Description of adult Eurghelmis cott1................. 13

Encysted motacercar1ae............................ I4

Exysted metacercariae............................. 15

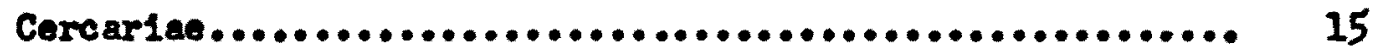

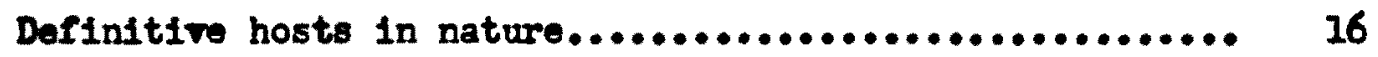

Reanlts of experimental infections...................... 16

A PARTIAL REVIEW OF THE STBFAMILI APOPHALITNAE CIUREA, 1924

DIagnosis of the subfanly Apophallinae................ 21

Loy to genera.................................. 21 
Dlagnosis of the gemus Apophallus.................... 21

Description of Apophallus muehlingt.................. 22

Dlagnosis of the genus Pricetrenz....................... 23

Degcription of Pricetrema zalophi................... 25

Dlagnosis of the genus Euryhelmis..................... 26

Rey to spectes of Euryhelmis........................... 28

Deseription of Buryholmis squamula.................... 29

Description of Euryholmis monorchis.................. 32

Description of Euryhelmis pacificus.................. 35

Deseription of Euryhelmis pyrtformis................. 4 .

Description of Euryhelinis costariceneis............... 43

DrscussIon...................................... 50

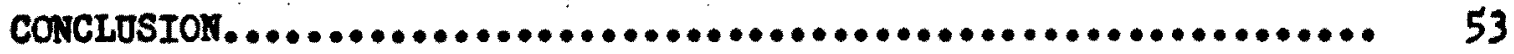

BIBLIOGRAPHI....................................... 54

APPENDIX A - EXPERIMENTAL INFECTION OF LABORATORY ANIMALS:

SOLOTIONS AND TECHNIQUES

Earle's Salt Solution............................... 57

0.9 Porcent Saline............................... 57

Pepsin Solution $(0.5$ percent solution)................ 58

Trypsin Solution (1 percent solution)................. 58

Infection of laboratory animals..................... 59

Aneathetizing small mammals......................... 60

APPEDIX B - FIXATION AND STATNING: SOLUTIONS AND TEChIQUES

Caradne Stains....................................

Mayar's Paracarmind .................................. 61

Semtchon's Carmine................................. 61 


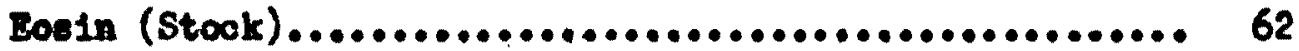

Fast Green.................................... 62

011son's Fixative............................... 62

Tochniques of fixation and staining................ 63 


\section{IIST OP TABIES}

TABLE

PAGE

I Hoterophyid I1fe cycles......................... 4

II Oregon atreams 8 ampled for Cottus spec1es Infected with wtacercarlas of Euryhelmis cotti.....................

III Comparative measurements of some members of the subfamily Apophallinas Clurea I924........................... 46 


\section{IIST OF FIGURES}

PIOURES

PAGE

1 Euryhelmis cott1 n. ep. ventral Hew................. 18

2 Buryhelmis cott1 n. Ep. dorsal viow.................. 20

3 Euryhelmis cott1 n. ep. transverse section through 20 tho gonoty 1 and rentral sucker.........................

4 Buryhelmis cotti $n$. sp. longitudinal section through the gonoty 1 and rentral sucker......................... 20

5 Apophallus muchlingi, ventral vieu of adult............ 24

6 Pricetrema zalophl, ventral view or adult............... 27

7 Euryhelofs equamula, ventral view of typical adult....... 31

8 Buryhelmis squamula, ventral view. Adult Make showing atrophy of Viteliaria on the right side of the animal..... 31

9 Euryholnts squamula motacorcaria.................... 31

10 Redia of Emyhelinds monorchie....................... 36

11 Gercarta of Euryhelmds monorehte................... 36

12 Maw cell pattern of Euryhelmis monorchis............. 36

13 Cercaria of Euryhelme monorchls showing penetration

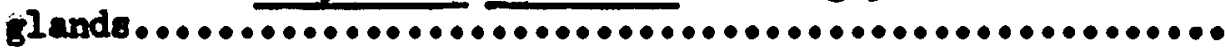

I4 Euryhelind monorchis, ventral viow of a typical adult..... 36

15 Euryhelnds pacificus adult, ventral view.............. 39

16 Excysted metacercaria of Euryhelmis pacificus............ 39

17 Bgg of Euryholmis pacificus...................... 39

18 Ventral sucker and gonotyl of Euryhelinds pacificus,

longltudinal section............................. 39

19 Dotype region of Euryhelmis pacificus................. 39 
V11

HoORES

PlaE

20 Euryhelmie pyriformis, doreal dew of adult............. 42

21 Burrhelnis costartconsio, dorsal dew of adult........... 45 


\section{IMTRODUCTION}

In examination of sculpins of the genus Cottus, collected in the Hohalen River near Vernonla, Oregon, revealed the presence of mang motacercariae of several different types of trematodes. Fotacercariae of heterophyld wore found amone these. The systematic position and life cycle of which have been investigated with results prosented in this study.

The beterophyld under consideration has been found to represent a new species of the genus Euryhelmis Poche, 1926. At the present time, five apecies have been described for the gemus as follows: Enryhelinie squamula (Rudolph1, 1819), Buryhelmis monorchis Ameel, 1938 Buryholmis pactefeus Senger and Macy, 1952; Euryhelwis pyriformis Wobater and Wolfgang, 1956 and Euryhelmis costaricensis Brenes and Arroyo, 1960. The adults have typically been found in the small intestine of mustelids and the metacercariae in amphibians. The complete Iife cycles have been described for Euryhelmis squamila (Anderson and Pratt, 1965), Euryhelmis monorchts (Aveel, 1938), and partially for Euryhelmis pac1f1cus (Senger and Macy, 1952). The 1tfo cycles of the species belonging to the genus Euryhelmis differ from the typical heterophyid in that the atacercariae are generally found in aphibians and not fish. (Seo Table I.)

The members of the fandly Heterophyldae are sall distomes or wonostomes, generally not more than 3 min in length, and are oval or prriform in shape. The antorior ond is more motile and less bully 
then the more posterior portion which generally containe the reproduotive organe of the adult. The cuticle is sping or scaly, either over the entire body or at least anteriorly. The ceca are long, and a cirrus pouch is absent. A gonotyl is present in the genital atrine. The acetabulum may be reduced and Incorporated into the will of the genital atriun and 1s lacking in come genera. Adulte of the fantly show a rery low host specificity. Most opectes are able to develop to maturity in the enall intestine of a rariety of varm blooded animale. As an example, Haplorehis taichui Mishigori has been doscribed from cattlo egrote (Africa, 1938), soa gullo (Witonberg, 1929), ducklings (Hox, 1951), cato and dogo (Kunte and Chandlor, 1956), Fulpes, ralpes (Kuntz and Chandler, 1956), and man (Africa, Dateon and Gareis, 1940).

The life cycles of the mombers are very eindlar. The adulte Imhabit the small Intestine of namals and birde that eat F1ah and aphiblanw. The exce are operculate and may contatn oarly cleavage etages or atracidia. The eggs are ingested by operculate snails in which one generation of sporocyst, one or two generations of rediae, and plemrolophocercus cercarias develop. The cereartee generally bave oral spines; kowever, the cercariae of Buryhelmis monorchis (Amoel, 1938) is an exception in that the cercarla lack oral spines. The cereariae leave the snail host and generally encyst in either freah water or marine 118h. Species of Euryhelids Poche, 1926 have been obown generally to encyst in amphtbiane (Ameel, 1938; Senger and Macy, 1952, and Anderson and Pratt, 1956) as does Metagonimoides oregonensis Price, 1931 (Burns and Pratt, 1953). 
This fanily 18 of particular interest because of its frequent cccurrence in the intestine of man. Stunkard and willey (1929) thought that every heterophyld was a potentlal human parasite. Although such a etatement is probably an overgeneralization, nembers of the fandly are frequently found in man, often causing serious complications (Africa, Garcia and DeLeon, 1935). The ora appear to be picked up by the lyuph or blood and carried to the heart, brain, epinal cord and 11ver. Martin (1958) found four heterophyid species that constitute a possible health hazard to in Hawaf1. Laird (1961) found what were assuned to be heterophyld egge in fecal concentrates from four percent of Tokeleuans examined. Apophallus ventrus Ransom, has been reported fron man in Canada (Cameron, 1937). Serious cases of Dietomiasis in western countries are reduced because fish are rarely eaten rax Intentionally. It is in the oriental areas, where improperly eooked or raw I1sh 18 customarily eaten that heterophyids present a derinite health problem. 
TABLS I

HETEROPHYID LIFE CYCLES

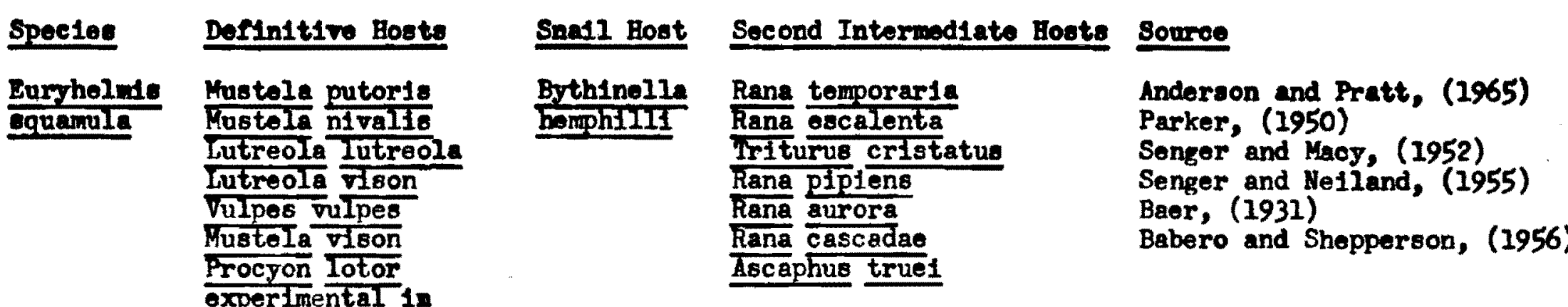

experimental 1n

hamster

\begin{tabular}{|c|c|c|c|c|}
\hline$\frac{\text { Euryholnts }}{\text { monorchis }}$ & mink & $\begin{array}{l}\text { Pomatiopsis } \\
\text { Iaptdarla }\end{array}$ & $\begin{array}{l}\text { Rana clandtans } \\
\text { experimental in } \\
\text { Rana plptens and } \\
\text { Rana palustrus }\end{array}$ & Amoel, (1938) \\
\hline
\end{tabular}

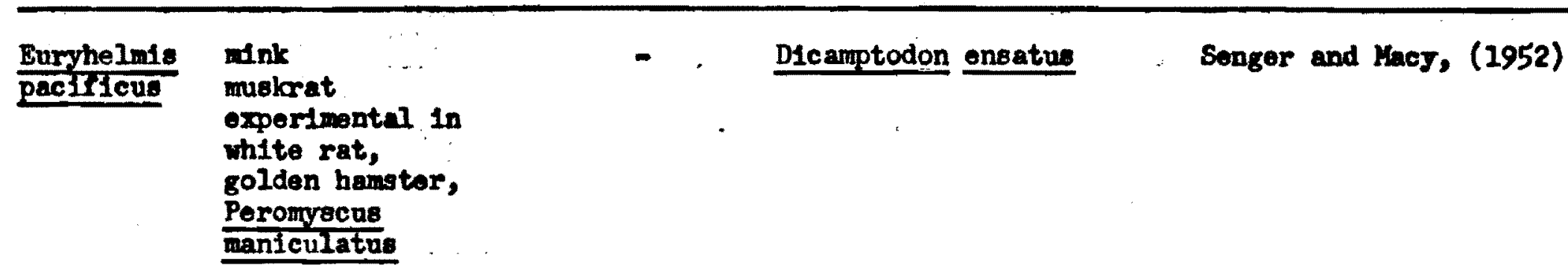




\begin{tabular}{|c|c|c|c|c|}
\hline Speotes & Definit1we Hoste & Sna11 Hoet & Second Intermodiate Hoete & Source \\
\hline$\frac{\text { Apopha1lue }}{\text { woehling1 }}$ & Larue ridibundus & - & - & Ransom, (1920) \\
\hline
\end{tabular}

$\begin{array}{lll}\text { Apophallus } & \text { rod skunk } & \text { Raysik1 and Fahug, (1962) }\end{array}$

Raysict and Pahum, (1962)

\begin{tabular}{|c|c|c|c|c|}
\hline$\frac{\text { Pricetrema }}{\text { zalophi }}$ & sea 11on & - & - & Price, (1930) \\
\hline$\frac{\text { Apophallus }}{\text { occentricus }}$ & $\operatorname{dog} 8$ & 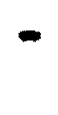 & - & Afrtea and Garcia, (1935) \\
\hline $\begin{array}{l}\text { Phagicola } \\
\text { Iagoniformis }\end{array}$ & $\begin{array}{l}\text { maskrat } \\
\text { oxperimontal in } \\
\text { chicks }\end{array}$ & - & Mmdulus pallidus & Martin, (1953) \\
\hline$\frac{\text { Ascoeotyle }}{\text { meIntoshi }}$ & Guara albe & - & - & Price, (1936) \\
\hline
\end{tabular}




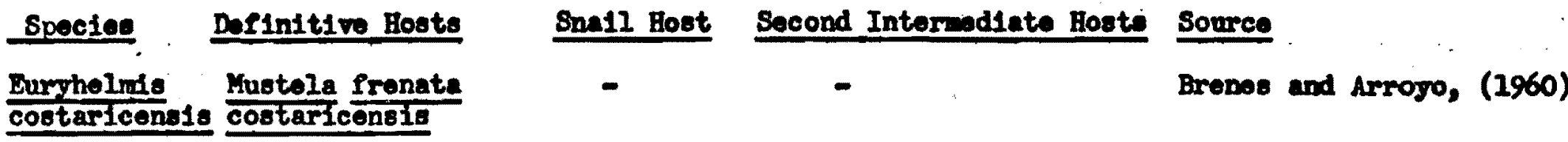

\begin{tabular}{lll}
\hline Euryhelmis & Mophitus \\
Dyriformis & - & Wobhitus
\end{tabular}

\begin{tabular}{|c|c|c|c|c|}
\hline$\frac{\text { Eurghelmis }}{\text { cotti }}$ & $\begin{array}{l}\text { Experimental in } \\
\text { mink, white rats, } \\
\text { wite mouse, } \\
\text { hamgter, chioks }\end{array}$ & - & $\begin{array}{l}\text { Irosh water rish } \\
\text { Cottus rhothreus } \\
\text { Cottus op }\end{array}$ & - \\
\hline$\frac{\text { Apophallns }}{\text { rentrue }}$ & $\begin{array}{l}\text { Arenherodias } \\
\frac{\text { herodias }}{\text { cats, dogs, }} \\
\text { raceoon, blue heron, } \\
\text { gulls }\end{array}$ & $\frac{\text { Coniobests }}{\text { IIroscens }}$ & $\begin{array}{l}\text { freah water flsh } \\
\text { Garpike; carp, } \\
\text { catfish, suckers, } \\
\text { small wouth bass }\end{array}$ & Camron, (1931) \\
\hline $\begin{array}{l}\text { Apophallus } \\
\text { bretie }\end{array}$ & 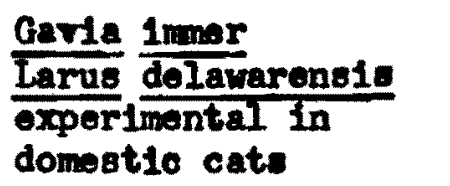 & $\frac{\text { Annteola }}{\text { Iimose }}$ & $\begin{array}{l}\text { freah water Iloh } \\
\text { trout }\end{array}$ & $\begin{array}{l}\text { Ransom, (1920) } \\
\text { Lyotor (1939) }\end{array}$ \\
\hline
\end{tabular}




\begin{tabular}{|c|c|c|c|c|}
\hline Spectes & Definitive Boote & Snall Hoot & Seocond Intermodicte Hosto & Soures \\
\hline$\frac{\text { Strictodora }}{\text { Eridactria }}$ & $\begin{array}{l}\text { exporimental in } \\
\text { chicks }\end{array}$ & $\frac{\text { Pironella }}{\text { contca }}$ & Aphanius fasciatus & Martin, (1955) \\
\hline$\frac{\text { Metagonimoldos }}{\text { Oregonensis }}$ & $\begin{array}{l}\text { raccoon } \\
\text { oxperimental in } \\
\text { hamsters }\end{array}$ & Coniobasio ep & Froge & $\begin{array}{l}\text { Price, (1931) } \\
\text { Burns and Pratt, (1953) } \\
\text { Lang and Gleason, (1967) }\end{array}$ \\
\hline $\begin{array}{l}\text { Parasitictodora } \\
\text { handeoch }\end{array}$ & - & $\frac{\text { Cerithidea }}{\text { odifornica }}$ & $\begin{array}{l}\text { G11lichthre } \\
\frac{\text { inrabilis cooper }}{\text { Fundulus parvipinnus }} \\
\text { parvipinnus }\end{array}$ & Martin, (1950) \\
\hline
\end{tabular}




\section{METHODS}

COLIECTINO FISH AND SNAILS

The most succeseful method for obtaining Ilsh of the genue Cottus wa found to be sweeping a Needham rake across the botton of a stroam. The sish inhablt the botton of the atream, often near the bank, frequontly under rocks, and In grase over-hanging the bank. Rocks wre overturned, and the Needham rake was swept through the vicinity. In graspy over-hangs, the rake was swept through the subwerged grass, often with excellent resulte. Snaile were obtained elther by sweeping the rake acrose the substrate or picking them out by hand. All collectIng was conducted in shallow water. The collector most of ten vearing hip boots. Collecting was nost auccessful prior to vinter flooding.

TRANSPORTING PISH AID SNATLS FROM THE FIELD TO THE LABCRATORY

The flsh and anails were placed in plastic cake pane half fllled with atream water with Otabs (Pemble Laboratories, River Falls, Wisconsin) added for aeration. The cake pans were covered and placed In styrofoam containers to which crushed ice had been added. This method of transporting $\mathrm{flsh}$ and snaslo from the field to the laboratory proved to be successul since the mortality rate was rery low.

\section{MUTNRAINING ANIMUIS IN THE LABORATORY}

The fiah were placed in aerated squarla and partially oubmerged In a soft drink cooler, which maintained the tomperature at $8^{\circ}$ centigrade. Water in the aquaris was changed about once a week. The water 
In the aquaria was obtainod by allowing tap wator to stand at room tomporature for several days, then cooling it to $8^{\circ}$ centigrade before roplacing the original water.

Fish were maintained in this way for at least a month and wore not fod during this period.

Snalls were kept in plastic cake pans wh1ch were placed efther In the soft drink cooler or in a cold room that was $3^{\circ}$ centigrade. The onails remained alive for at least a month.

OBTAININO METACERCARIAE

The fish wore keyed to species, and each spectes was thes oxamined for cysts. When it was observed that several species contained the hoterophyld motacercariae, the species were no longer soparated. The fish were killed by pithing, weighed and then ground with a meat grinder. The cround fish wer then placed in a digestive solution (weo appendix) and allowed to digest for about one hour at $37^{\circ}$ cent1grade with gentlo agitation. The digest was then strained and diluted with 0.9 percent saline. Diluted digest was allowed to set for twenty minutes, then the supernatant was slowly poured off and more 0.9 percent salino was added. After allowing fiftoen minutes for settling, material from the bottom of the beaker was pipetted into a Potrl dish. The cysts were then observed under a dissecting microscope. The cysts were separated according to morphological type using an eye dropper and placed in Stender disher containing 0.9 percent saline solution.

IIFECTING LABORATORY ANTMALS

Laboratory animals were infected either by force feeding 
concentrated suspensions of metacercariae or by feeding them fish collected from an area of known infection. The latter method was ucod in work atilizing mink (Mustela rison) because of varjous problems in handing these animals. Force feeding was employed wth all other animals. Mamal feeding was done in one of two ways, elther feeding cyste to a conecious animal using an eyedropper or by rondering the animal semiconscious with other or chloroform and Infecting then by means of a syringe and tubing. (For a detalled aecount of the procedures used in infecting animals see the appendix.)

ifter infection the anfmals wore kept in cages with a water oupply but were not fod. Infected animels were generally kept a maximum of four deys. Antmals were killed with chloroform or ether, and the intestine was removed immediately and placed in 0.9 percent saline solution. The Intestine was cut into approximately 4 centimeter lengthe and placed in Petri dishes with 0.9 percent saline and then slit open. The linear arrangement of the remored intestine was maintainod by numbering the dishes. The Potri diohes were then covered and allowed to atand for aproxdmately thirty minutes giving ang Ilukes present tim to move from the rills of the inteatine to the botton of the Petri dish. The Intestine was then scraped and teased apart to remore any trematodes that had not moved from the rill1 within the thirty minute period.

Trematodes were transferred with an eyedropper to Stender dishos contalning 0.9 percent saline. The flukes were then studied alive under the compound microscope; various detalle of the anatong were observed, and neasuresents were taken. The Plukes were then f1xed In 01lson's fluid, flattened under cover slip pressure and stained 
wth elthor Ehrilch's acid homatoxylin or caraine stains. Katerial to be sectioned was not flattened, but merely fixed in Gilson's Iuid. I datalled account of the rarious procedures inrolved in fiding and atelning w111 be found in the appendix.

\section{ECTSTATION OF METACERCARTAR}

Ketecercarise obtained after pepain digestion were excyeted oltber weohanically or chemically. The nature of the cyst wall and the smull alse of the organieme dealt with in this research dictated the use of ensymatic treatment. The in vitro excystation techniques exployed were after those of Macy, Berntzen and Benz (1968). Dotalls of come of the mechanical and chemical procedures arailable w1ll be found in the appondix.

Lfter excystation, the metacercartas were placed in 0.9 percent saline and otudied allve. They were then fixed and otained by the same procedures as were the acults. Excysted motecercarlae vere maintained 11Ving for several daye in 0.9 percent saline at a temperature of $18^{\circ}$ centigrado.

\section{EXAMIMIIG SWAIIS FOR CERCARIAE}

There are several mothods commonly exployed in attempting to find the cercarlal form. One any attempt to find the cercartae ofther by eracking enalls or by allowing the cercarlae to be shed naturally from the sall. The firot method entalled crushing the onalls by otriking them with a light hammer, and picking away the sboll fraguento wth dissecting needles. The shell-pree tisoue was placed in 0.75 percent saline and observed under a dissecting microscope. The bepatic tisene was teased apart to expose any oporocyste, redias, 
and cercariae which might be present. The second wathod employed natural ohodding of cercariao from the ana11s. Snalls were placed in Potrl dishes, four snails per dish. The dishes were filled about onehalf full with water and partially covered to retard evaporation of wator, and the onalls were allowed to stand at approxdmately $25^{\circ}$ centigrade for twenty-four hours. The dishos were then examined for cercariae under a dissecting meroscope. 
RESULTS

Fioh of the gemus Cottus were collected from various atreand In Northwest Oregon. (See Table II.) When netacercariae obtained from the fich were ingested by laboratory animals, adult hoterophyids were obtalned. Bxamination of a number of these flukes Indicated that they represented an undeseribed species of the genus Buryhelmis Poche, 1926. All measuremente are in microns unless otherwlse stated. The average 18 followed by the extremes in parentheses.

DESCRIPTION OF ADULT BURYHELMIS COTTI

Buryhelinds cott1 n. sp. (F1gures 1,2,3 and 4)

Specif1c diagnosis: Buryhelmis: Body thin, leaflike, spinose overal exepting extreme posterior; pyrform or elongate. Iength 419 (270 to 550) width 222 (150 to 290). Oral oucker elther terminal or eubterninal $39(32.5$ to 42.5$)$ long by $45.65(37.5$ to 55.0$)$ in diamater. Pharynx spherical, 26.25 (25 to 30 ) in diameter connected to the oral encker by a short but definite prepharynx 8 (7 to 9) in length rery apparent in living material but often not evident in fixed material. Bsophagus slender, blfurcating anterfor to the acetabulun; length from the posterior espect of the pherynx to the cecal bifurcation 91.25 $(62.5$ to 140$)$. The ceca extend obliquely towards the sides and then follow the contour of the body, terminating at the extreme posterior of the animal, being somowhat enlarged at their posterior ondo. Leotabulum 28.95 (25 to 29) in dianeter situated slightly pro-oquator1al. A sight but definite constriction in the body wall at the level 
of the acetabulum. Testes oroid, opposite or oblique in the posterior part of the body; the right testis generaliy located slightly posterior to the left. Right testid 97.0 (76 to 152.5) wide, 67.5 (55 to 80) anterio-posterior ads. Seminal resicle sac-like, dorsal to uterus and posterior and to the right of acetabalna. Cirrus not erident. Conital atrium located Immodiately anterior to the acetabulua and overhung by a bilobed gonotyl. Conotyl appears as a bllobed fold of tisone rather than a sucker. Uterus consisting of three to four 100ps confined between intestinal ceca, testes, and acetabulum, opens into the genital atrium. Ovary, located on right side and anterior to right testis, somewhat club-shaped 56.25 (37.5 to 67.5 ) wide; 44.1 ( 40 to 50 ) long. Seminal receptacle, located between right testis and ovary, spherical or club-shaped. Neither Iaurer's canal nor Kohlis' glend were observed. Vitelline follicles numerous, follicular, confined laterally, extending from the level of the acetabulam to the posterior ond. Egge operculated, with polar thickenings, 32.5 ( 30 to 37 ) by 20.5 (16 to 22.5 ). Excretory bladder, $Y$ or $T$ ahaped, extending forward from the posterior ond of the body between the testes and bifurcating immodiately anterior to them.

Boste: (experimental) Mustela Nision, white rat, white mouse, golden homater, chicke.

Habitat: small intectine

Iocality: Northwest Oregon, O.S.A.

EMCYSTED METACERCARIAE

The metacercariae are found in Cottus rhotheus and several unidentified species of the genus Cottus. Infection in these fish 
10 comon. The matacercaries are found encysted in the somatic maculature of the 11sh. The cyste are ovold, 198.15 by 145.00 . Mthough numerous in pepsin digest, the cysts are difficult to locate in Ireah material. The cyet wall is tough, approximately 7 thick, and composad of three distinct larers, an outer opaque layer approsimtely 3 thick, a middle clear leger about 2 thick, and a dark innernost layer 2 thick. The motacercarla within 18 doubled on 1tself, and jellowish granules are numerous. Numerous yellowtsh granules are typical in the metacercarid cysts of heterophyids. The motacercariae within the capsule are generally active; the excretory bladder is typically fllled with black droplets. The oral and ventral enckere are apparent as is the gonotyl, and the cuticle is distinctly eplnose.

\section{EXCYSTED METACERCARIAE}

Breyted animals are very active and have comparatively wall. dereloped reproductive organs; the tostes are orold, and the ovary is elub-ohaped to spherical. The Vtolline glands are evident but not fully developed. The testes are not yet producing spern. Stained and mounted speciwons avorage 222.5 long by 142.25 . The oral sucker is 40.45 (37.5 to 45.0) in dianeter. The pharymx averages 22 in diameter and 18 connected to the oral sucker by a definite propharynx 8.75 in length. The intestinal ceca are present. The ecetabulum averages 26.15 in dianoter. The gonotyl also is present.

\section{cerchrtas}

The cercarla and snail host for Euryhelmis cotts have not been desertbed. Snails of the genera Oxytremma and Fluminicola were 
collected from the same localities as were the fish. Snalls were exanined for cercarlise by dissection and shodding. The results were negative. Approximately 1,000 snalle wore examined.

DETINITIVE HOSTS IN MATURE

Bfforts to locate animale naturally infoctod with Euryhelmie cott1 were negative. One raccoon, Procron lotor, a road k1ll was examined. The animal vas found along the Sunset Highway soveral niles west of Bearerton, Oregon. Four sea gulls (Larus sp.) wore collected from a land fill operation one-half mile north of Orogon City, Oregon. The birds wore shot with a 12 gauge shot gun and taken imredlately to the laboratory for examination.

\section{AESULTS OF EXPERTMENTAL INPECTIONS}

The anlmal experimentally infected with metacercarlae have been noted previously. The fluke appears to be rery adaptive in regard to maturing to the adult condition in a variety of warm blooded rertebrates and therefore has a low specificity relative to dofinitive hosts. In all cases whore experimental infectione were attenpted, ogg-producing adult flukes were recovered. The tim required for aturation to the adult from metacercaria is relatively short as ecc-producing adults were obtained from an experimontally infocted hanster 17 hours after infecting this aninel with metacercariae. These resulte mag have been influenced slightly by previous treatment In the popsin digest. This treatment has been shown to have an effect on the cyet wall of Sphaeridiotrena globulus (Kacy, Berntzon, and Benz, 1967). The effect of the pretreatment is probably 
17

Insignificant since the metacercariae are relatively well-developed as was observed in expysted metacercariae. Animals infected wore routinely killed after three or four days, and in all cases, mature nukes were recovered.

In comparison to body 8120 , the $98 \mathrm{gg}$ produced by Euryhelmis cotti are extremely large. Also, at any given time, the number of egg present in an adult did not exceed twenty. The average number of eggo per adult is about sixteen. The number of eggs found in these Nukes 18 very small in comparison to the number found in mot adult beterophyids. 


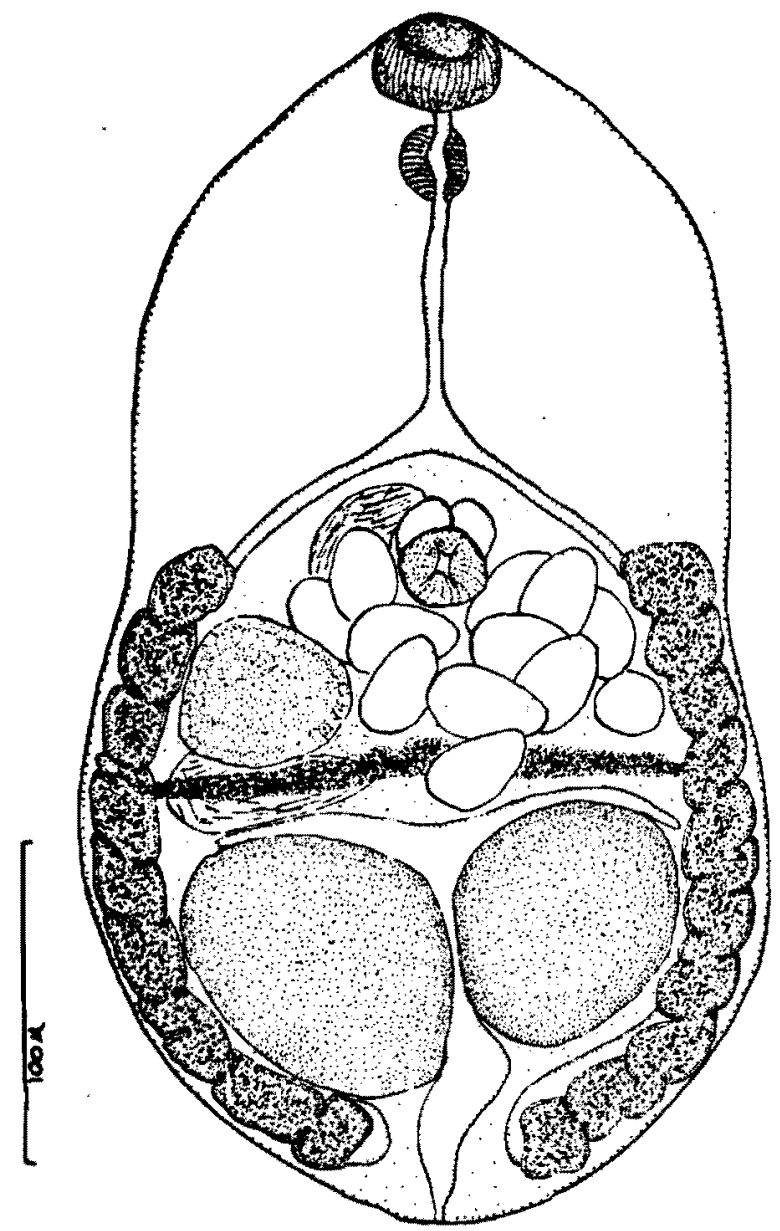

Figure 1. Euryhelmis cotti n. sp. ventral view. Adult specimen from the small intestine of an experimentally infected hameter; three days post infection. (original) 
TABLE II

ORDOON STREAMS SAMPLED FOR COTTUS SPECIES

INFECTED WITH METACERCARIAE

OP EURYHELMIS COTTI

Strean

Clackamas RIVer

Cyotal Springs

Mill Creek

risll Croek

Molalla River

Nate Creek

Tehalem River

Tillamook River

WIlson RIver
Locality

Botacada

Portland

Colton

Turner

Holalla

Colton

Vernonla

Cosst

Coast
Infoetion

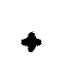

$+$

$+$

$+$

$+$

$+$

$+$

$+$ 

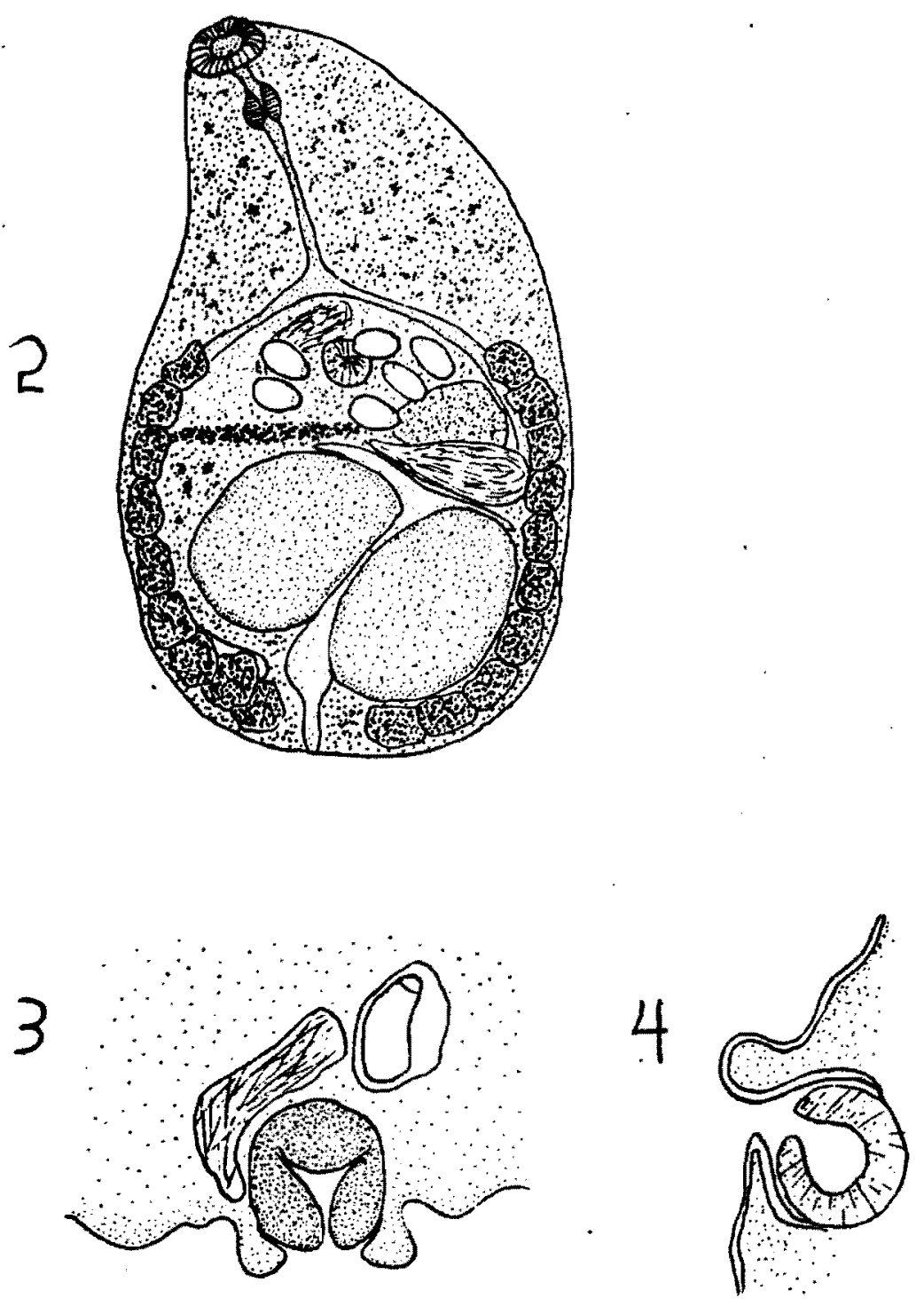

Figure 2. Euryhelmis cott1 n. sp. dorsal view. Specimen from the small intestine of a hamster; 17 hours post infection. (original)

Flgure 3. Euryhelmis cotti n. sp., transverse section through the gonotyl and ventral sucker. (original)

Figure 4. Euryhelmis cotti n. sp., longitudinal section through the gonotyl and ventral sucker. (original) 
\ PARTIAL REVIBW OF THE SUBFAMLII APOPBALLIMAE CIUREA, 1924

\section{DIAGOSTS OF THE SUBFAMILY APOPHALLINAE}

Since Eurybelmis, to which the new species , belongs, is Included In the subfadily Apophallinae, a reviow of this group is presented.

Subfanily diagnos1s: Hoterophyidae: Body elongate to pyriform or elliptical. Oral sucker rather small, exceptionaliy large. Eeophagus long, ceca terminating at or near posterfor extremity. cetabulum enclosed in genital atrium, may be large or small. Testea diagnonal, occasionally juxtaposed, near posterior extrenity. Seminal realole uinding or divided. Cenital pore median in widdle third of body, somet1mes more anterior. Ovary submodian, pretesticular; recepteculum seminis present. Dterus anterior to testes. V1tellaria extending in lateral fields almost whole lengtb or greater part of Intestine. Excretory vesicle I-shaped. Parasitea of birds and mamals.

\section{ISI TO GENERA}

1. Prepharynx short, lenth being less than esophageal length -- 2

Ib Prephargnx longer than esophagus - - Pricetrema

2a Body anch elongated, esophagus long, excretory vesicle I-shaped, steri long and sigmold, passing between the testes -a.- Apophallus

2b Body quadrilateral or pyriform, esophagus short, excretory vesicle I or I-shaped, short stem passing between testes -..- Euryhelints

DIACMOSTS OP THE GENOS APOPHALIUS

Apophellus Lube 1909 (F1gure 5) 
Generic diagnosis: Heterophyidae; Apophallinae; prepharynx present but much shorter than the long esophagus. Bifurcation of intestins nearer to rentral sucker than to oral eucker. Intestinal ceca extend Into the posterfor end of the body well bohind the testes. Fentral meker modian, sbout midray of the body, openine to the exterior through the genital pore. The genital sinus, which opens to the exterior through the cenital pore, and in which the vas deferens and ragina terminate, is situated immediately in front of the ventral sucker. Well-doveloped seminal vesicle bohind the ventral sucker. Teates globular or oval, in posterior third of body, the right testis nevally obliquely behind the left, but the two may be side by side at the same level. Seminal receptacle in front of and to the right of the left (anterior) testia. Orary globular, on the right side of the modian 11ne, in front of the seminal receptacle. Vitallaria extend forward to about the level of the ventral sucker, may be 11 inted to the lateral fields in this region, but may extend imward to the modian IIne in front of the rentral sucker. Posteriorly the lobules of the ritellaria are numerous behind and between the testes, and often are present on the dorsal and ventral aides of the testes. Traneverse ritelline ducts located in the neighborhood of the boundary between the ovarian and testicular zones. Uterus disposed in a fow loops in the median field, none in front of the genital pore.

DESCRIPTION OF APOPEALUUS MUEHLINOI

Type species: Apophallus muehlingi (Jagerakiold, 1899) Lube, 1909 Speciflc diagnosie: Apophallus: Longth, 1,200 to 1,600; wldth, 190 to 230. Body mech elongated, constricted near the middle in the region 
of the rentral sucker. Cutanoous scales, 2.9 long. Oral sucker, 54 in diameter. Prephargnx well-developed (about as long as the diameter of the oral sucker according to Muehling's 1llustration). Phargnx, 37 In dianeter. Testes globular, near the posterior end of the body; right testis obliquely behind the left. Ventral sucker of about the sam aize as the oral sucker. Cenital einue median, immediately in front of the rentral sucker. Seminal vesicle well-developed, S-shaped, In modian Iine behind the ventral sucker. Ovary globular or pyriform, on right side of body between testes and sucker. P1tollaria do not extend antoriorly beyond the level of the rentral eucker and do not meroach upon the median field in this neighborhood. Posterforly they are numerous in the median fleld behind the tester, between then, In front of them, and on the dorsal sides of the testes. Otorus relatively short, containing only a fow ogge, which are brownish in color, 32.4 long by 18 wide.

Bost: Larus ridibundus

Babitat: Intestine

Locality: East Prussia

DIAONOSIS OF THE GENUS PRICETREMA

Pricetrema Cinrea, 1933 (Figure 6)

Genoric diagnosis: Heterophyldae, Apophallinae; body elongated pyriform, spinose. Oral sucker subterminal, comparatively large. Prepherynx distinct. Eeophague shorter than prepharynx, ceca extending to near posterior extremity. Acetabulum smaller then oral sucker, fust post-equatoriel, opening into genital atrium. Testes situated side by side in posterlor fourth of body. Seminal 


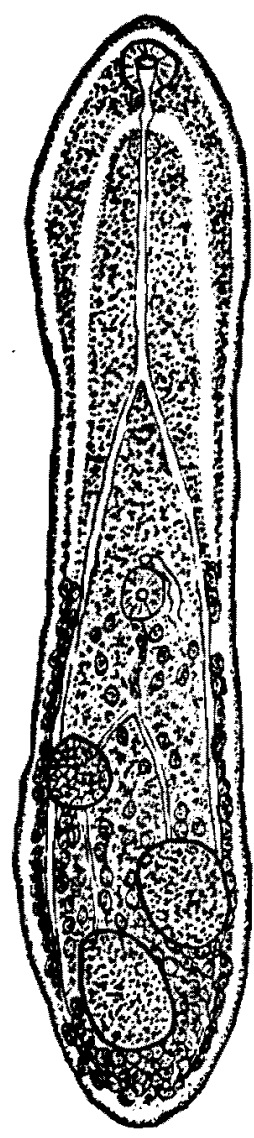

Figure 5. Apophallus muehlingi, ventral view of adult. (redrawn from Ransom, 1920) 
reatele C-shaped, very roluminous, encircling acetabulum. Two gonotyls present, one on each side of genital pore. Ovary bubmedian, enterior to right testis. Receptaculum seminis posterior and dorsal to orary. V1tellaria consisting of large, closely packed follicies, extending from level of pharym to anterior and of testes, extenalve doreally, but confluent ventrally noar intestinal bifurcation only. Uterine coils confined to intereecal field between testes and genttal pore; egge small. Intestinal parasites of marine manmals. DSSCRIPTIOK OF PRICETREMA ZALOPHI

Price (1932) Incorrectly placed the species in the gonus Apophallus. Cimrea (1933) erected the genus Pricetrema for the species. The following spectelc diagnosis is from Price (1932).

Type spec1es: Pricetrema zaloph1 (Price, 1932) C1urea, 1933 Spectiflc diagnosis: Pricetrema: Body elongated pyrtform in shape, 435 by 215 to 263 wide at the level of the orary. The cut1cle is besot with small scalellke epines, 4 long by 2 wide, arranged in alternating transverse rows. Oral bucker elightly subterninal in position, 60 to 75 in diameter. Prepharynx 30 to 33 long; pharynx oroid to epherical in shape, 29 to 33 wide; esophagus 18 long; Intestinal ceca relatively wlde and extending to near the posterior end of the bodys thoir blind ends belng hidden by the testes. The acotabulum is circular, 52 to 60 in diameter, situated from 235 to 259 from the. anterfor end of the body and enclosed in the shallow genttal sinus. The genftal ducts open into the anterior part of the sinus, and two alliptical gonotyls are present, one on each side of the genital aporture. The seminal vesicle is voluminous, more or less C-shaped 
and Ifing to the right of the acetabulum; there is a sharp constriction of the reeicle near the level of the posterfor margin of the acetabulan which divides it into an anterior pyriform part and a posterior globular part. The testes are somewhat triangular In ontiline, 81 to 96 by 81 to 110, and are situated side by side In the posterior fourth of the body. The orary is more or 1888 triangular in outline, 55 to 75 by 67 to 92 , situated a short distance cephalad of the right testis. The senjnal receptacle is opherieal, 44 in dianoter, and situated dorsal to the ovary and right testis. The Vitellaria consiats of large, closely packed follioles, which extend from the lovel of the acetabulun to the level of the anterior margin of the testes; the follicles are dietributed over the entire dorsal surface but rentrally they are chlefly lateral except near the intestinal bifurcation where they form a distinct band across the body. The uterus consists of a fow loops confined to the Intercecal field between the anterior margin of the testes and the genital aperture. The egge are 33 long by 18 wide, golden Jellow, and silghtly pyriform in shape.

Boat: Zalophus callforneanue

Babitat: omall Intestine

Iocal1ty: North America ( United States National Zoological Park, Washington, D.C.)

DILONOSIS OF THE GENUS EURYHELMTS

Buygheluis Poche, 1926

Cenerle diagnosis: Heterophylidae, Apophallinae, body small, Mattened, 1eafike. Excretory bladder I or T-8haped. Testes, one transitory 


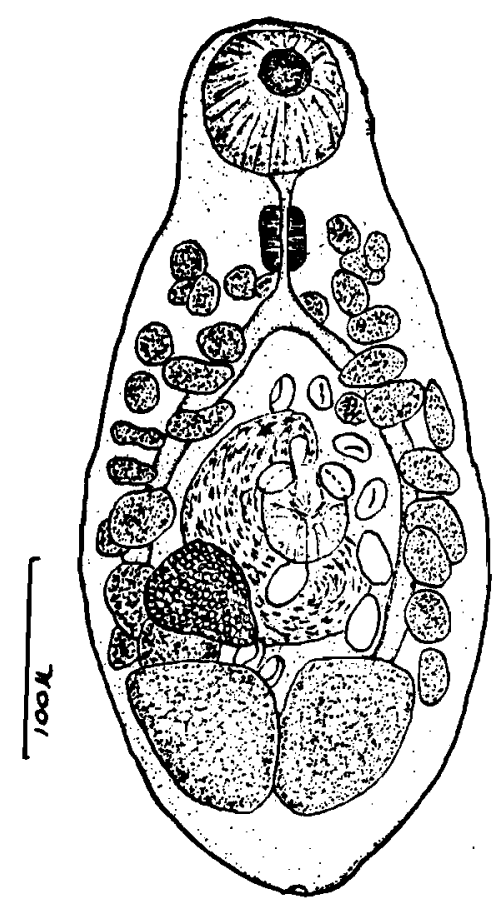

Figure 6. Pricetrema zalophi, ventral view of adult. (redrawn from Price, 1932) 
or two, spherical or lobate, in the posterior half of the body. Cirras and cirrus pouch absent. Seminal vesicle present or absent. Oterus with only an ascending 1imb, relatively short, confined between the Intestinel ceca. Vitelline follicles numerous, mainly Iateral, extending from near the intestinal bifurcation to the posterior region of the body. Cral sucker, acetabulum, pharynx, and esophagus present. Prepharynx present or absent. Intestinal ceca long, extending to the posterior extremity of the body. Centel atrium immediately anterior to the acetabulum, overhung by a bllobed, fold-11ke gonotyl. Egg8 operculated, with or without olight polar thickening.

\section{IEI TO SPECIES OF EURYHELMTS}

Ia Body quadrilateral, wider than long or wdth and length nearly equal, oral sucker omaller than acetabulva -

Ib Body not as above, generally pyriform, oral sucker larger than acetabulum -

2a no testes present $-10-3$

2b RIght testis present, left absent, seminal receptacle often reduced or absent, $\operatorname{egg} a 1 z 629 \times 14$-- E. monorchis

3a Vitellaria dendritic, vterus mainly in left portion of body, egge $34 \times 15-2$.

3b Vitellaria follicular, uterus lies in both left and right portions of the body, egge $29 \times 16 \ldots$ 4a Tro testes present 5 
Lb Right testis present only, ritellaria dendritic

antorfor to acetabulum follicular posterior,

egg: $28-34 \times 18-23$ -

5a Vitellaria extond to level of intestinal bifurcation,

-gge 20-34 × 10-17 -

5b Vitellaria follicular, extend to level of acetabulum,

dofinite constriction in body wall at level of

scetsbulum, oggs $32.5 \times 20.5 \ldots$

DESCRIPTION OF EURYHELMIS SQUAMULA

Type spec1es: Eurrhelmis squanula (Rudolphi, 1819) Pocho, 1926 Spectifle diagnosis: Euryhelmis. Body wider than long, spinose, Length 600 to 1,000 , width 1,400 to 1,900 . Oral sucker 70 in dianeter. Prepharynx nearly spherical, 50 by 60 . Eeophagus well-developed, length rariable. The esophagus bifurcates anterior to the acetabulun, and the ceca follow the contour of the body to the posterfor. Ventral sucker 100 , in the middle of the body. The genital atrium opens inmodiately anterior to the acetabulum and is overhung by a genital papillac. Testes are lobed or globular, lie on elther side of the median at the posterior of the body. Seminal vesicle to convoluted upon 1tself, confined to the right half of the body and opens ria - short ejaculatory duct into the genital pore. No copulatory organ. Oterus conslating of three or four loops, confined mainly to the left olde of the body, opens into genital atrium to the left of the ejacnlatory canal. Orary club-shaped, liee on right alde, anterior to right tostis. Seminal receptacle elub-ghaped, lies between right testis and ovary. Laurer's canel present. Vitelline follicles dondritic, extond 
from intestinal bifureation to posterior of body, following the ceca. rohlis' gland present. Eggs operculated, with polar thickening $34 \times 15$. Hosts: Mnstela putorius L., Mustela nivalis L., Lutreola lutroola Wagner, Lutreola Vison Schreber and Vulpes Nilpes L. in Europe (Baer, 1931); Mustela rison Schriber, Procyon lotor, experimentsl house cat (KeIntosh, 1936), and golden hasster (Anderson and Pratt, 1965) in U.S.A.

Habitat: omall Intestino

Ife cycle: Anderson and Pratt (1965) described the life cycle for Duryhelmis squamula in Oregon. Prior to then a number of definitive and secondary intermediate hosts were known. The first Intermediate host in Oregon was the opereulate onall Bythinilla hemphilli PIlobry. The following is a description of the cercarlae from Anderson and Pratt (1965). Lophocerous, sp1nose. Ta1l fin attached to poster1or two-thirds of dorsal surpace of tail, around tip and up rentral surface of posterior one-third of tall. Vigorous suimer, body spinous. Oral sucker ringed with two rows of minute spines. Acetabulum smaller than oral sucker. Digestive tract not spparent. Twelve spherical penetration glands in posterfor half of body, ducts leading in mass to oral suoker. Genital primordium present but undifferentiated. Excretory bladder large. Excretory duct from bladder onds dorsally, slightly posterior to base of tall. Flam cell formila $2(2+2+3+2)$. Moasmements of I1ving cercaria body length 146 (122 to 195), width 68 (61 to 85), tall 211 (195 to 229) long by 24 (22 to 29) at base, oral sucker 33 (22 to 44 ) and ventral sucker 18 (15 to 22 ). Red1se are elongate, colorless, simple, smooth, active. Gut 


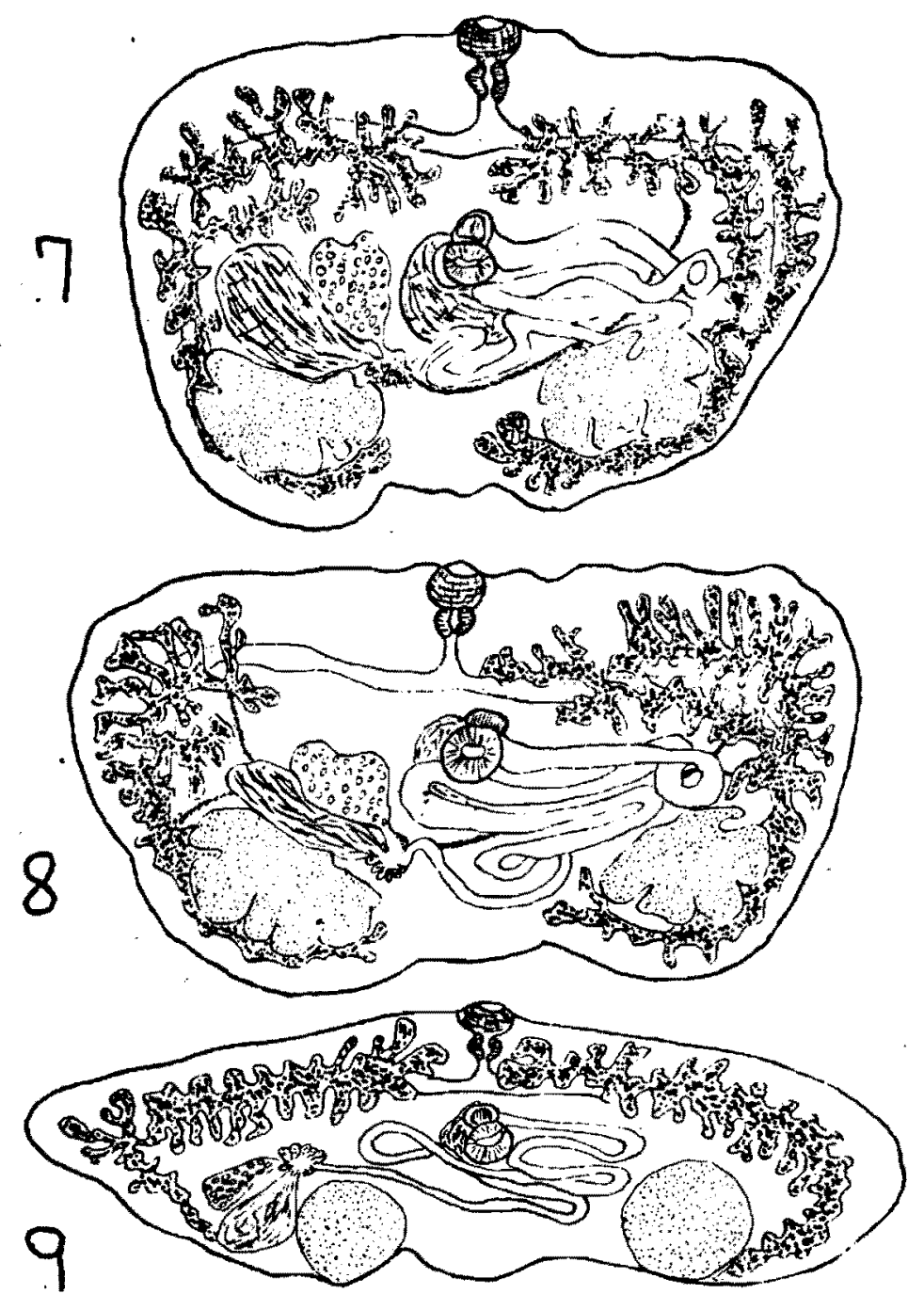

Figure 7. Euryhelmis squamula, ventral view of typical adult. Figure 8. Euryhelmis sauamula, ventral view. Adult fluke showing atrophy of vitellaria on the right side of the animal. Figure 9. Euryhelmis squamula metacercaria

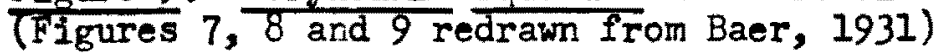


seal1, Indiotinct. Length 674 (434 to 788), width 151 (131 to 272), phargax 37 ( 32 to 41 ).

The metacercarlae were firet found in Europe (zeller, 1867) encysted undor the oken of the brown grass frog, Rana temporar1a, and were later roported from Rana esculenta, Tritura cristatus and toads (Baer, 1931). In the Unfted States the metacercariae of Durghelmie squamula have been found in Rana pipiens in Virginia (MeIntosh, 1936), in Rana aurora, Rana cascadae (Senger and Macy, 1952), and Ascaphue trues (Anderson and Pratt, 1965) in Oregon. Andorson and Pratt (1965) note that Buryhelmis squamula has a body longth and width ratio that is nearly equal. It appears that this is ceneral for material in the United States. Measurements from Europenn matarial show the width to be greater than the length. (Figures 7,8 and 9)

DESCRIPTIOH OF EURTHELMIS MONORCHIS

Euryhelimis monorchis Ameel, 1932 (Figures 10, 11, 12, 13 and 14) Spectfic diagnosis: Euryhelmis. Body thin, loaflike, transparont, nevally much broador than long, spinose. Length, 440 (390 to 460); greatest wdth, 610 (520 to 690). Oral sucker 41 (32 to 48 in anterioposterior, 59 ( 48 to 67.2 ) in tranoverse diameter. Fentral sucker 60 (40 to 64) in enterio-posterior, 69 (62 to 76) in transverse d1ameter. Conotyl ("genitel sucker") about 32 by 48. Phargax large, opherical, lmpinging on oral sucker, 33 (32 to LO) by 35 (32 to 43 ). Soophague slender, bifurcating close to ventral sucker. Intestinal cees extending diagonally to sides, then to posterior region of body. Testis ono, small, spherical, on right side near posterior end of body. 
Seminal resicle absent. Ovary dextral, elliptical or lobate. Sominal receptacle large, between ovary and excretory bladder. Uterus usually consisting of three loops confined to region limited by ventral oncker, excretory bladder, orary and left limb of intestine. Laurer's canal present. Mehils' gland well-developed. Vitelline follicles numerous, largely lateral, extending frow stem of excretory bladder to bifurcation of intestine. Eggs operculate, undeveloped when laid, $29(25-30)$ by $14(12-14)$. Excretory bladder I-shaped, large and conspicuous.

Eosts: Primary, Mustela Fision Schreber and, experimentally, white rat and domestic cat; first Intermediate, operculate snail, Pomatiopsis lapidaria Say; second intermediate, Rana clamitans Latrellle and, experimentally, R. pipions Shreber and $\underline{R}$. palustris to Conte. Babitet: small intestine of primary host Iocallty: the UnIted States - Wisconsin, Ohio (Napoleon) and Michigan (Jackson, Ann Arbor, Flushing and hittehall).

Cercarlae are lophocerous, spinose. Total length, 360 (330 to 390); body length, 110 (100 to 120); body width, 40; tail length 250 ( 230 to 270). Oral sucker, 22 ( 20 to 24 ) in diameter. Approxdmately 12 penetration glands in third fourth of body. Ducts in a central mass anterior, bifurcating posterior to the oral sucker. Exeretory bladder is large and $\nabla$-shaped. Genital primordium lies between the excretory bladder and penetration glands. Ventral sucker 1s small, weakly developed, and rentral to genital primordium. Mother rodia gives rise to daughter redia. The rediae are simple, without appendages, rugose to smooth and are active. A birth pore is present. 
Length 670 ( 530 to 850); width 130 (120 to 150). Pharynx 32 (32 to 33) In diameter. Out small and clear, 20 ( 14 to 28 ) by 20 (16 to 24 ). Adulte wore recovered from the small intestine of naturally Infected mink and of laboratory infected cats and rats. Specimens from rato were found to be smaller than those from mink. Mature adulte containing as many as 52 egge were obtained three and one-half days post infection from rats. The flukes were located in the duodenum at this timo. After sixteen days post-infection, the majority of nukes were observed in the jejunum.

One characteristic feature of the adult worm is the transitory nature of the aingle testis and associated structures. The majority of the opecimens observed lacked the male genital system entirely. Only 2.7 percent of the Euryhelmis monorchis observed possessed a testis which was always on the same side of the body as is the orary. Amoel (1932) postulated that the testis is present for only a brief period In the 11fe of the adult, degenerating after the production and discharge of sperm.

The first intermodiate host is the operculate snall, Pomatiopsis 1apidaria. Cercariae were present in 5.1 percent of the snalle collected near Ann Arbor, Michigan (Ameel, 1932). They are active swimmers, the periods of activity alternating with periods of rest when the cercaria einke to the botton in a characteristic flexed position. The cercariae of Duryhelnis monorchis differ from other heterophyid cercariae in that ther lack eyespots and a row of double spines around the oral aperture. The tall of the corcarta is several times longer than the body. The finfold extends from near the base of the tail dorsally to the 
tIp and 10 present on the posterior third, rentrally. The tip of the tall is observed to be rery contractile and in continuous motion in an active corcaria.

Junorous cystogenous glands are present. The genital primordium appoare 20 a mass impediately posterior to the penotration glands. The rontral sucker is weakly developed. The oxcretory resicle 1s large and conoplcuous. Excretory tubules were not traced but nine flame cells per side were observed with an apparent pattern of $2(2+2+3+2)$.

The cercariae penetrate froge and tadpoles, and a blister is formed at the point of entry.: Blieters were observed over the entire body surface of tadpoles, but they were confined largely to the limbe and the lateral and ventral arese of adults that were experimentally exposed to corcarlac. The authors falled to find infected tadpoles in nature, but 66 percent of Rana clamitans collected from endemic areas vere. Infocted with the metacorcariae. Rane plpiens and Rana palustrie from the same area were negative although these species were readily infocted in the laboratory.

Yetecercariae are located in the subcutaneous connective tissue. The eyet consiets of a thin inner wail apparently secreted by the carcarlae and a thick pigmented layer of host origin. Metacercarlae are Infoctive forty-five days post infoction. Minty-one and three tenthe percent of the motacercariae have aipgle testis present; 8.7 percent are lacking the male reproductive structures.

DESCRIPTION OF EURYHELMTS PACIFTCUS

Euryhelmis pacificus Senger and Yacy, 1952 (F1gures 15, 16, 17, 18 and 19) 

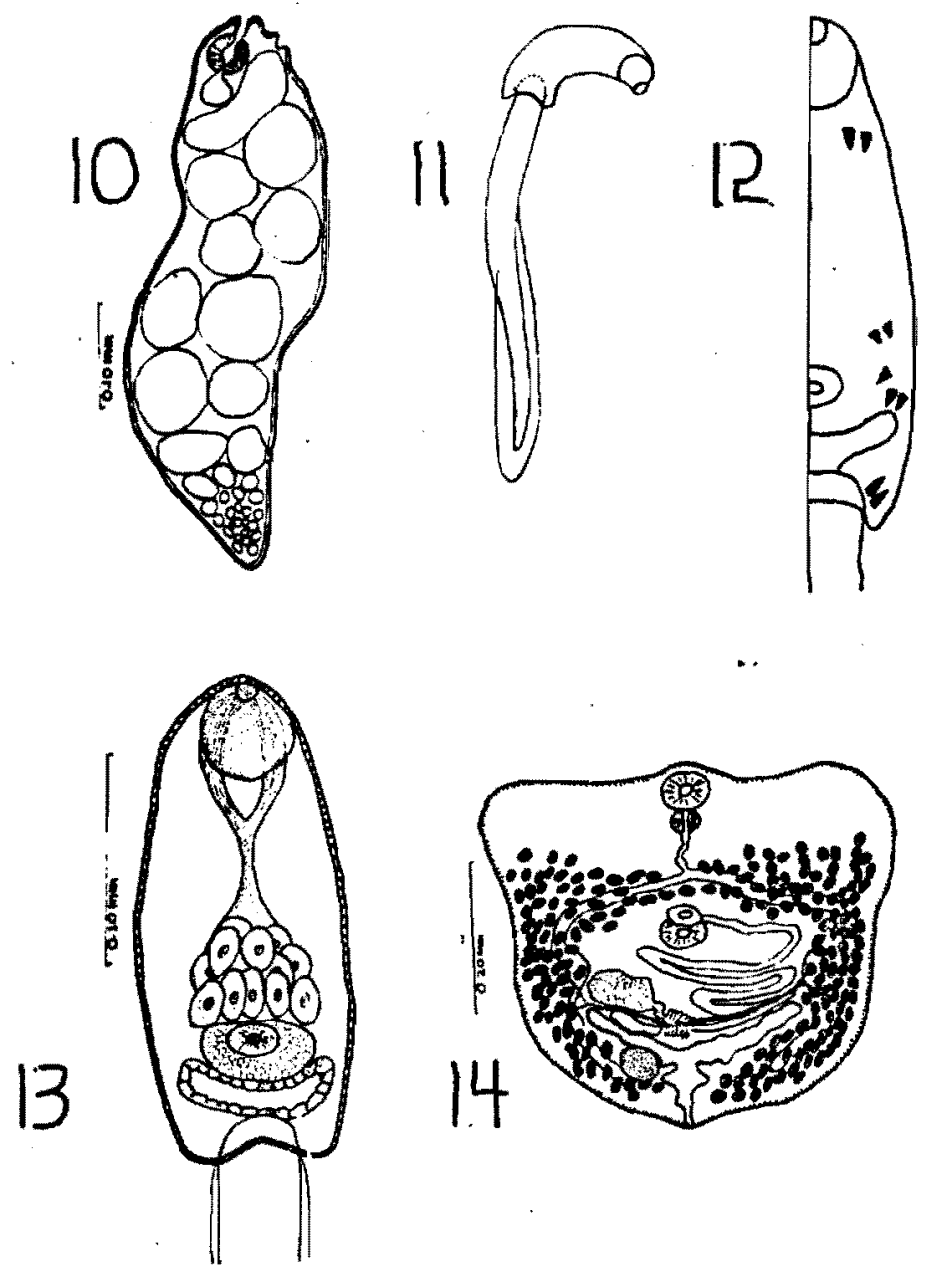

Figure 10. Redia of Euryhelmis monorchis

Figure 11. Cercaria of Euryhelmis monorchis

Flgure 12. Flame cell pattern of Euryhelmis monorchis

Flgure 13. Cercaria of Euryhelmis monorchis showing penetration glands.

Figure Ih. Euryhelmis monorchis, ventral view of a typical adult.

(Figures 10 through 14 redrawn from Ameel, 1938) 

oanal originates as a medial elongation of the seminal receptacle and after some coiling opens on the modian dorsal ourface somewhat posterior to ootype region. Mehlis' glend well-developed, located to the left of orary,". Vitelline follicles numerous, confined Iatorally, extending from noar the bifureation of the intestinal cecs to the posterior end. Eggs operculeted, 20 to 34 by 10 to 17 in preserved material; 14 by 31 in fresh material. Excretory bledder I or T-shaped, extending forward from the posterior end of the bod between the testis and bifureating immodiately anterior to them.

Bosts: Mustela Nioion Schrober, Ondatra zibethica Linnaeus and (experimental) wh1te rat, golden hamster and the field mouse Perongscus maniculatue Wagner; adults without egge in Sorex bendirif palmert.

Habltat: small intestine

Iocality: Oregon, J.S.A.

Ldulto are found in Mustole vision, Sorex bendiril palmeri, and Ondatra zibethica. Experimentally the Flukes dereloped in the whito laboratory rat, golden hamster and the deer mouse Peromyscus mantoulatue. The flukes found In the shrex were derold of eggs, and the derelopment of eggs in the deer mouse was poor. The absence or poor developwent of eggs is suggestive of an incompatability between parasito and host.

It was observed that the Iukes required forty-elght hours to reach maturity in the wite rat and seventy-two hours in the golden hamster. The adult flukes inhabit the duodenura of the hoet. 

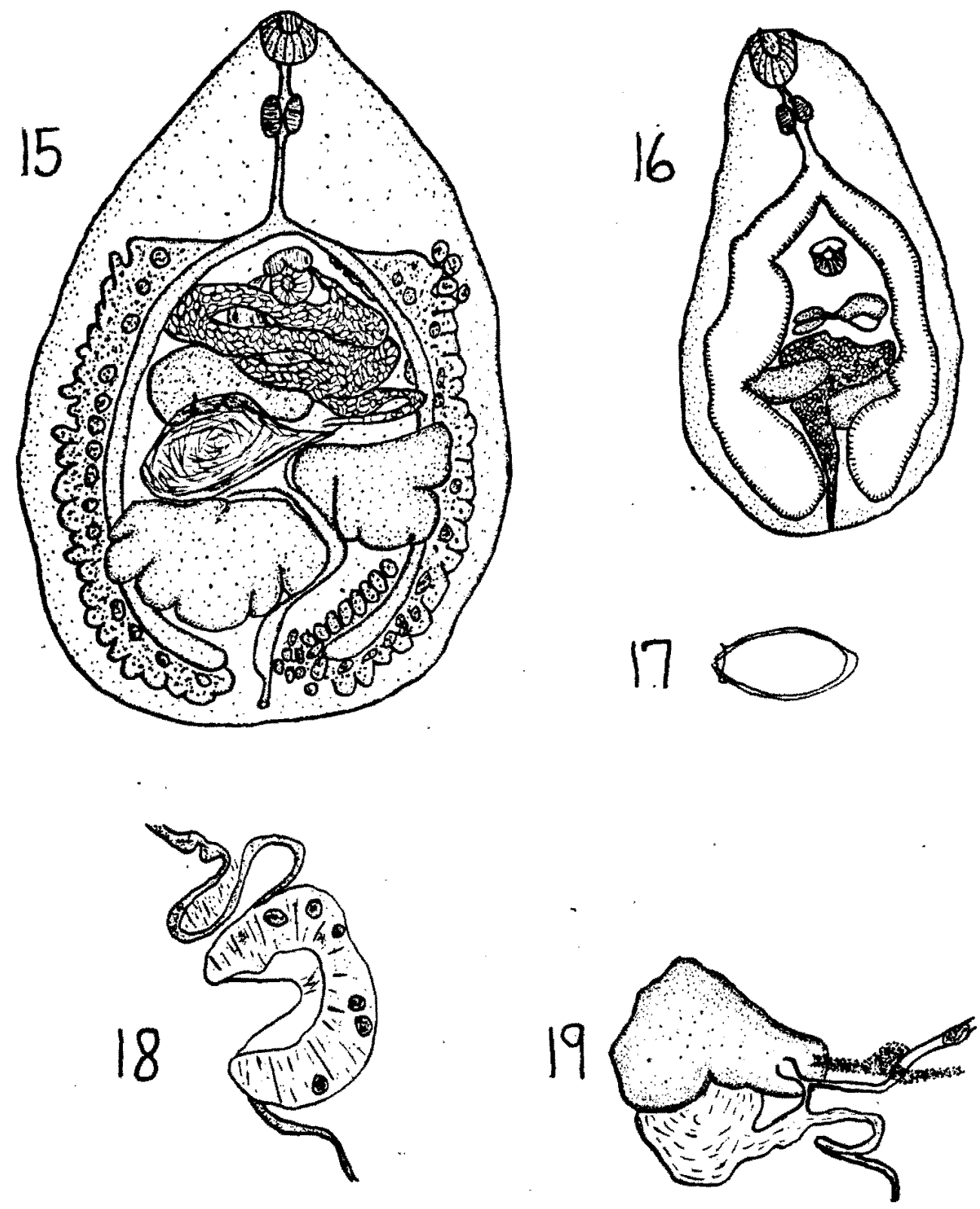

Figure 15. Euryhelmis pacificus adult, ventral view.

Figure 16. Excysted metacercaria of Euryhelmis pacificus. Flgure 17. Egg of Euryhelmis pacificus.

Figure 18. Ventral sucker and gonotyl of Furyhelmis pacificus, Iongitudinal section.

F1gure 19. Ootype region of Euryhelmis pacificus.

(Figures 15 through 19 redrawn from Senger and Macy, 1952) 
The snail intermediate host and consequently the cercariae for Barybelmie pacificus are not known. The motacercarlae are reported only in the Pacific Giant Salamander, Dicamptodon ensatus in Oregon. The larval form of this amphtblan is abundant in many of rocky streame of the Coast and Cascade Ranges in Oregon. Incidence of infection of the salamanders examined was found to be approxdmately 90 percent. The number of metacercariae per animal varies from five or six to several mundred with an average being approximately fifty cysts per animal. The oysts are located in the striated muscle of the host and not in the subeutaneous connective tissue where, in froge, the cjots of Euryhelmis wonorchis, and Euryhelmis squamula are found. It appears there is no preference for encystront as the metacercariae are rather evenly distributed throughout the tissue. The cysts are surrounded by a jellowish loose connective tissue capsule of host origin.

Excysted motacercariae are active, and the reproductive organs are woll-developed. The Intestinal ceca of many of the excysted metacercarlae are packed with discrete bodies of ancertain nature. The excretory bladder contains discrete droplets, presumably of respiratory by-products. The gonads and genital ducts are easizy seen in living metecercariae; testes are spherical and not producing sperm; the ovaries are oral or club-shaped; the seminel receptacle 18 spherical in shape and is lined wth cilia as were the oviduct, Laurer's canal, and the duct leading to the ootype. The cilla beat actively. The primordia of the uterus and seminal vesicle appear to be devold of cilie.

The Itfe cycle of Euryhelmis pacificus is completed when the infected salamander, Dicamptodon ensatus to eaten by a sultablo host. 
The natural host in nature for this fluke 18 mink with the maskrat belng apparently a suitable but probably not uncommon one.

DESCRIPTION OF EURYHELMIS PYRIFORMIS

Buryhelmis pyriformis Wobster and Wolfgang, 1956 (Figure 20) Specifie diagnosis: Euryhelmis. Body thin, leaflike, transparent, pyriforn or elongate, spinose anterlor, lacking posterior. Length 2,250 ; wdth 570 at the level of the acetabulum. Oral sucker weakly macular and territnal 100 in diamoter. Pharynx 50 by 70 and is contiguous with oral sucker. Bsophagus 600 branches 250 from acetabulum into two ceca which terminate a short distance behind the testis. Acetabulum 90 transverse diameter and is depressed within a large papilliform gonotyl 230 traneverse diameter. The gonotyl appears to surround the sucker and folds over the genital pore imodiately anterior to acetabulum. Single testis large lying near the left cecum in posterfor of body. The sexinal vesicle is clubshaped, bends medially beneath the left odge of the gonotyl, and terminates in common with short ejaculatory duct, at the genital pore. Orary is triangular and Iles lateral and slightly posterior to seminel resicle, broad at posterior becoming narrow at anterior; along the left side it follows the contour of the ceca. Seminal receptacle, 150 In transverse diameter, contiguous with, and posterior to, the ovary. It opens in common with the orlduct and common yolk duct Into the ootype. There is no distinct Mohlis' gland, and Laurer's canal was not observed. Oterus consists of three compact and transterse colls. Bgge 28 to 34 by 18 to 23 and have a distinct operculum. Titelline glands of two morphological types: dendritic 


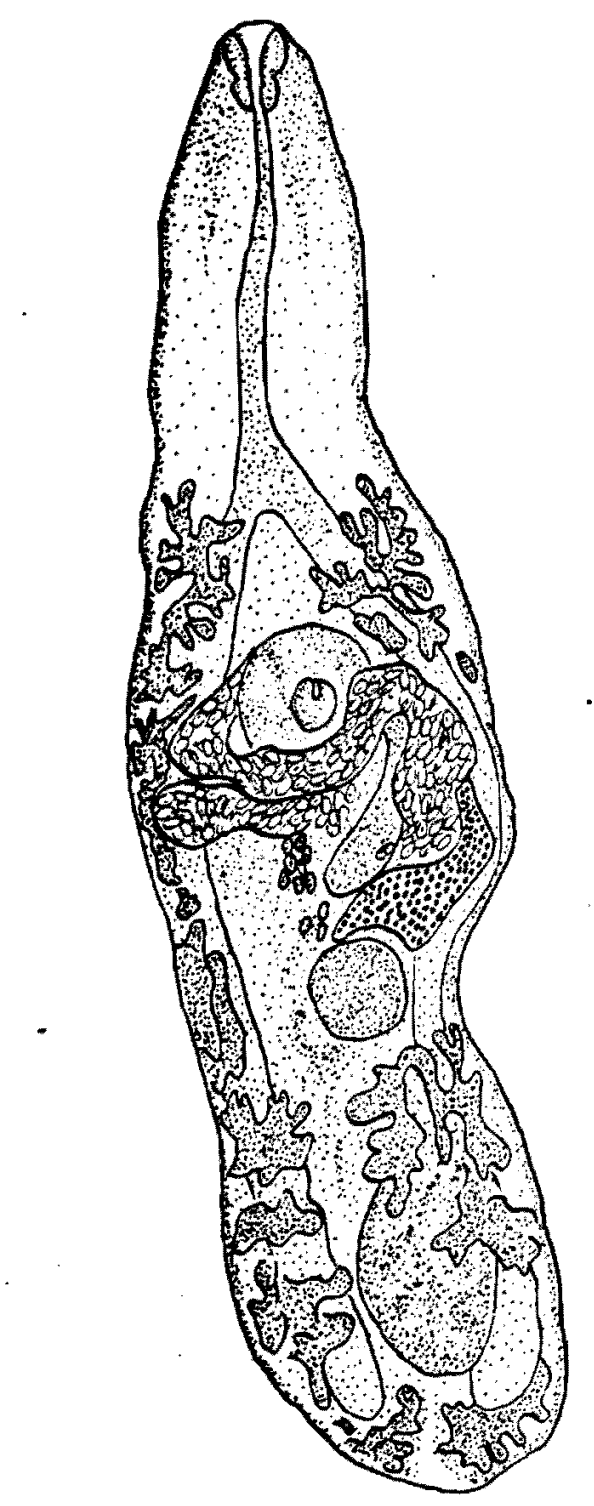

Figure 20. Euryhelmis pyriformis, dorsal view of adult. (redrawn from ebster and nolfgang, 1956) 
anterfor to acetebralum and follicular in the posterfor of the fluke. They are confined to the ceca and extend from the end of the esophagus to the posterior of the body. Excretory bladder I-shaped, terminating in a papillifor sallence. Hoot: Mephitis wephitis

Habltat: omall intestine

Locelity: Ste Anne de Bellerue, Province of Quebec DESCRIPTION OF EURYHEIMIS COSTARICENSIS

Duryhelmis costaricens1s Brenes and Arroyo, 1960 (F1gure 21) Specific diagnosis: Euryholmis. Body thin, quadrangular, transparent spinose. Longth from 1,074 to 1,281; w1dth 716 to 854 . Oral sucker subtorminal 73 to 80 by 53 to 82 . Pharynx 64 by 48 . Eaophagus 115 to 161 long, 11 to 13 in width. The intestinal ceca extond obliquely to the stdes, then follow the contour of the body to the posterior. Ventral sucker slightly pre-equatorial, length 96 to 101 , width 96 to 110 . Gonotyl situated immediately anterior to the acetabulum 73 by 52. Testes lobed, situated in the posterfor of the body, bounded by the ceca, the right testis being located more posterior than the left. Right testis 277 transversely, 193 anterio-posterior. Left testis 230 tranoversely, 184 anter10-posterior. Ovary anterior to the right testes, elongated traneversely, 29 by 230 . Oterus confined between Intostinal coca, acetabulua and testes, opens into the genital atrium. Melthor Yeblis' cland nor Leurer's canal were observed. Vitelline flands follicular, mostly extracecal but may be cecal and intercecal, extend from the cecal bifurcation to the posterior of the body. seminal receptacle located betweon right testes and ovary, transrersely 
- longated, 184 by 298. Eggs small operculated, 29 by 16.

Bost: Mustela fronata costaricensis

Babitat: small Intestine

Locallty: EI Alto, Tres R108, Proviola de Cartago. 


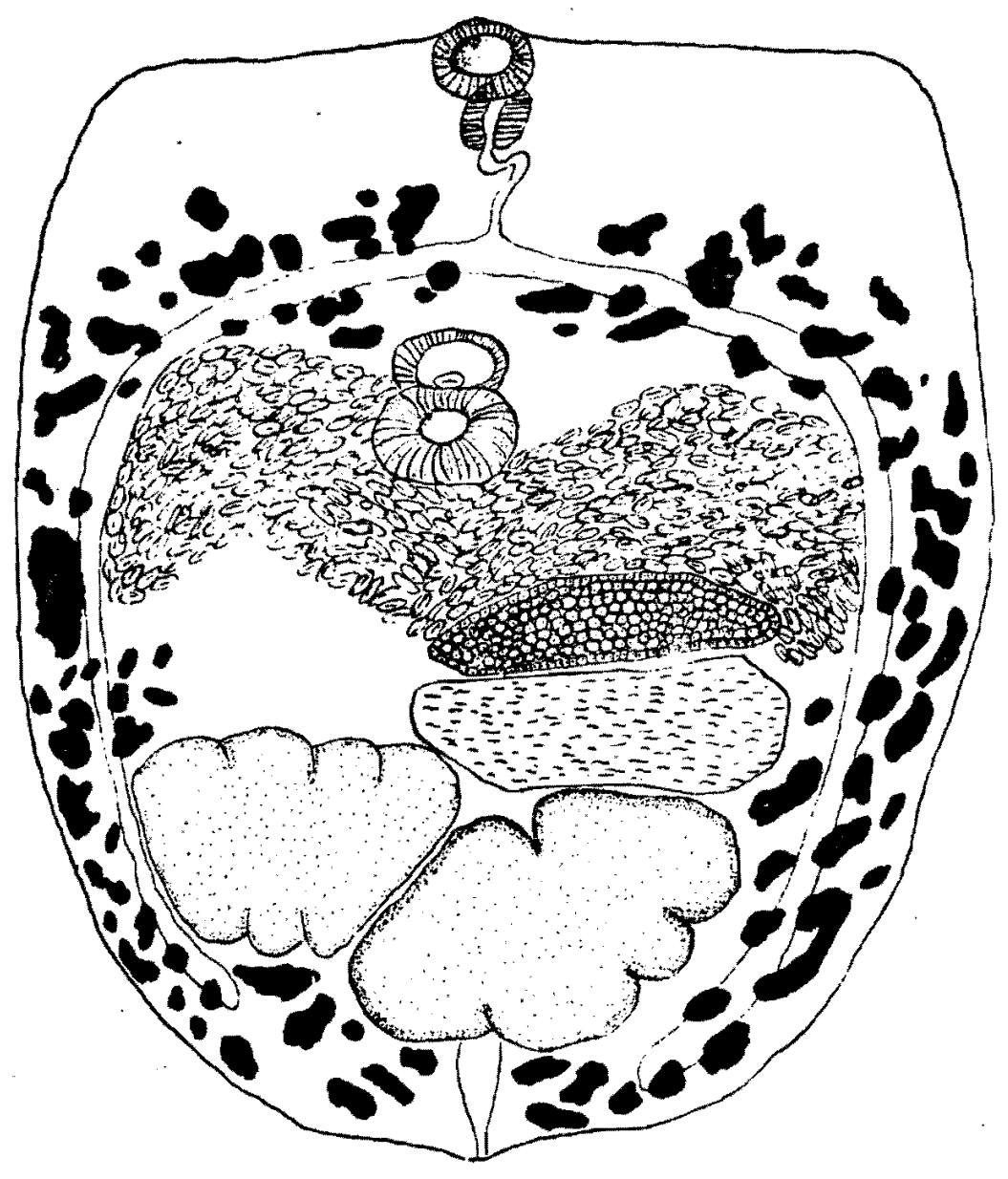

Figure 21. Euryhelmis costaricensis, dorsal view of adult. (redrawn from Brenes and Arroyo, 1960) 


\section{TABLB III}

COMPARATIVE MEASIREMENTS OF SOME MEMBERS OF THE SUBFAMTLI APOPHALLINAE CIUREA 1924 (MEASURED IN MICRONS)

\begin{tabular}{|c|c|c|c|c|}
\hline & $\frac{\text { Euryholmis }}{\text { squamula }}$ & $\frac{\text { Euryhelinds }}{\text { monorchis }}$ & $\frac{\text { Euryhelmis }}{\text { paciricus }}$ & $\frac{\text { Euryhelmis }}{\text { pyritormis }}$ \\
\hline Body length & $600-1000$ & $440(390-460)$ & $660-1040$ & 2250 \\
\hline Body wdth & $1400-1900$ & $610(520-690)$ & $340-680$ & 570 \\
\hline $\begin{array}{l}\text { Oral Sucker } \\
\text { diameter }\end{array}$ & 70 & $59(48-67)$ & $49-90$ & 100 \\
\hline Pharynx & $50-60$ & $33 \times 35$ & $35-59$ & $50 \times 70$ \\
\hline Pre-Pherynx & & & $39(4-100)$ & \\
\hline Esophagus & & & & 600 \\
\hline Ventral Sucker & 100 & $60(40-64)$ & $35-62$ & 90 \\
\hline $\begin{array}{l}\text { Right Testis } \\
\text { Iongth }\end{array}$ & & - & $180-320$ & \\
\hline wdth & & & $100-160$ & \\
\hline $\begin{array}{l}\text { Left Testie } \\
\text { length }\end{array}$ & & absent & $150-260$ & absent \\
\hline width & & & $140-180$ & \\
\hline Qonoty 1 & & $32 \times 48$ & & \\
\hline $\begin{array}{l}\text { Ovary } \\
\text { length }\end{array}$ & & & $100-250$ & \\
\hline vidth & & & $70-240$ & \\
\hline $\begin{array}{l}\text { Sowinel } \\
\text { Receptacle }\end{array}$ & club-shaped & & $\begin{array}{l}70-230 x \\
60-160\end{array}$ & 150 \\
\hline Es: & $\frac{30-32}{14-16} x$ & $\begin{array}{l}25-30 x \\
12-14\end{array}$ & $\begin{array}{l}20-34 x \\
10-17\end{array}$ & $\begin{array}{l}28-34 x \\
18-23\end{array}$ \\
\hline
\end{tabular}


TABLE III (continued)

\begin{tabular}{|c|c|c|c|}
\hline & $\frac{\text { Eurybelmis }}{\text { costaricensis }}$ & $\frac{\text { Euryhelmis }}{\text { cotti }}$ & $\frac{\text { Pricetrema }}{\text { zalophi }}$ \\
\hline Body length & $1074-1281$ & 49 & 435 \\
\hline Body width & $716-854$ & 222 & $215-263$ \\
\hline $\begin{array}{l}\text { Oral Sucker } \\
\text { dlameter }\end{array}$ & $53-82$ & 45.65 & $60-75$ \\
\hline Pharynx & & $26.25 \times 26$ & $29-33$ \\
\hline Pro-Pharynx & & 8 & $30-33$ \\
\hline Eoophagus & & 91.25 & 18 \\
\hline Ventral Sucker & $96-110$ & 28.95 & $52-60$ \\
\hline $\begin{array}{l}\text { Right Testis } \\
\text { length }\end{array}$ & 277 & 97 & $81-96$ \\
\hline width & 193 & 67.50 & $81-110$ \\
\hline $\begin{array}{l}\text { Loft Testis } \\
\text { length }\end{array}$ & 230 & 79.7 & $81-96$ \\
\hline width & 184 & 66.5 & $81-110$ \\
\hline Conotyl & $73 \times 52$ & & b1lobed \\
\hline $\begin{array}{l}\text { Ovary } \\
\text { length }\end{array}$ & 29 & 56 & $55-75$ \\
\hline width & 230 & 44 & $67-92$ \\
\hline $\begin{array}{l}\text { Seminal } \\
\text { Receptaclo }\end{array}$ & $184 \times 298$ & & 44 \\
\hline EgB & $29 \times 16$ & $\begin{array}{l}32.5 \times \\
20.5\end{array}$ & $33 \times 18$ \\
\hline
\end{tabular}


TABLB III (continued)

\begin{tabular}{|c|c|c|c|}
\hline & $\begin{array}{l}\text { Apophallus } \\
\text { dontcus }\end{array}$ & $\frac{\text { Apophallus }}{\text { meuhling1 }}$ & $\begin{array}{l}\text { Apophallus } \\
\text { crams }\end{array}$ \\
\hline Body length & $500-11140$ & $1200-1600$ & $1500-1900$ \\
\hline Body width & $200-390$ & $190-230$ & $279-341$ \\
\hline $\begin{array}{l}\text { Oral Sueker } \\
\text { diamoter }\end{array}$ & $65-85$ & 54 & $45-60$ \\
\hline Pharynx & $30-44$ & 37 & 30 \\
\hline Pre-Phargnx & short & short & short \\
\hline Bsophagus & $135-265$ & & 337 \\
\hline Ventral Sucker & $45.58 \times 48.60$ & & $\begin{array}{l}\cdots \\
\quad 52-62\end{array}$ \\
\hline $\begin{array}{l}\text { Right Testis } \\
\text { length }\end{array}$ & $80-200$ & globular & $150-160$ \\
\hline width & $60-200$ & & $187-210$ \\
\hline $\begin{array}{l}\text { Left Teatis } \\
\text { length }\end{array}$ & $80-200$ & globular & $180-187$ \\
\hline width & $60-200$ & & $180-187$ \\
\hline Conotyl & bllobed & & b1lobed \\
\hline Ovary & $65-140$ & globular & $75-97$ \\
\hline vidth & $40-120$ & & \\
\hline $\begin{array}{l}\text { Seminal } \\
\text { Receptacle }\end{array}$ & $\begin{array}{l}35-90: x \\
60-130\end{array}$ & & $\begin{array}{l}50-67 \times \\
60-82\end{array}$ \\
\hline B86 & $\begin{array}{l}30-35 x \\
16-20\end{array}$ & $32.4 \times 18$ & $33 \times 25$ \\
\hline
\end{tabular}


TABLE III (continued)

\begin{tabular}{|c|c|c|c|}
\hline & $\frac{\text { Apophallus }}{\text { 1oroux }}$ & $\frac{\text { Apophallus }}{\text { ventrus }}$ & $\frac{\text { Apophallus }}{\text { brerls }}$ \\
\hline Body longth & $850-930$ & $950-1450$ & $600-900$ \\
\hline Body wdth & $168-172$ & $250-550$ & $130-260$ \\
\hline $\begin{array}{l}\text { Oral Sucker } \\
\text { diemoter }\end{array}$ & $24-26$ & 60 & $30-50$ \\
\hline Pharynx & $16-18$ & & $20-28$ \\
\hline Pre-Pharynx & $31-36$ & & 20 \\
\hline Esophaqus & $123-144$ & & \\
\hline Pontral Sucker & $33-37$ & 60 & $35-55$ \\
\hline $\begin{array}{l}\text { Right Testis } \\
\text { Iength }\end{array}$ & $74-90$ & $150-200$ & $45-120$ \\
\hline ddth & $74-90$ & $150-200$ & $45-145$ \\
\hline $\begin{array}{l}\text { Loft Tostis } \\
\text { length }\end{array}$ & $70-82$ & $150-200$ & $45-120$ \\
\hline Mdth & $70-82$ & $150-200$ & $45-145$ \\
\hline Conotyl & & bilobed & \\
\hline $\begin{array}{l}\text { Orary } \\
\text { Iongth }\end{array}$ & 74 & 150 & $60-90$ \\
\hline wdth & 74 & 100 & $50-80$ \\
\hline $\begin{array}{l}\text { Seminal } \\
\text { Receptacl. }\end{array}$ & & & $40-60$ \\
\hline$E_{86}$ & $29 \times 17$ & $\begin{array}{l}26-32 x \\
18-22\end{array}$ & $\begin{array}{l}36-40 x \\
16-22\end{array}$ \\
\hline
\end{tabular}




\section{DISCUSSIOR}

Euryhelmis cotti resembles Euryhelmis pacificus more than it does the other members of the genus. It is, however, easily differentiated from Euryhelmis pacificue on the basis of its omaller body size and the nature and extention of the ritellaria. The ritellaria in Duryhelmis cotti extends from the level of the acetabulum to the posterior of the body; whereas, the ritellarla in Buryhelnis pacificus extends from the intestinal bifurcation to the posterfor of the body. Euryhelmis cotti differs from all the members of the genus whose life cyeles have been partially or fully described in that Burgheline cott1 utilizes a fleh for the second intermodiste host. Aphiblans servo as the socond intermediate host for Euryhelmis equamale, Euryhelmis monorchis and Euryhelmis pacificue.(See Table II.) Another notable difference is the afse of the egge in relation to body o1ze, and the small number of eggs found in Euryhelnts cott1. The eggs of Eurybelmis cott1 are largest in reletion to the body of the fluke than are the eggs of any other species of the genus.

The genus Euryhelmis was proposed by Poche, 1926 for Distomum equamula (Rudolphi 1819) which was poorly described. A complete description of Euryhelmis Equamule was published by Baer (1931) and Collot (1946) who gave measurements of the adult. Ameel (1938) described Euryhelmis monorchis with a report on its life cyele. Amoel placed the genus Euryhelmis in the subfamily Heterophylinae. Price (1940) rerlewed the superfamily Opistorchioldea, placing the genus 
Duryhelinds in the subfantly Apophallinae C1urea, 1924 of the fanily Beterophyldae. Price's conception of the subfamily was based on the following characteristics: (1) acetabulum relatively well-developed, enclosed in a small muscular genital sinus, (2) genital aperture pre-acetabular, and (3) gonotyl single or double, papillae-like. Morosor (1950) erected the subfamily Euryhelninae for the genus Duryhelinta based on Euryhelmis squamala and Euryhelmfe monorchis. Ho used the following charecteristics as basis for the subfamily: (1) a sngle lobed papizla-form gonotyl; located in front of the acotabulum, (2) Ntollaria occupying all the lateral apace from the pharynx to the posterfor of the fluke, (3) body wider than long, and (4) uterus typically with throe loops. Senger and Macy (1952) described Euryholmis pacificue with notes on its life cycle and amended the genus. They wero in agreement with Price (1940) that the genus should be placed in the subfamily Apophallinae. Webster and Wolfgang (1956) described Eurybelds pyriformis from a single specimon, and they agreed with Price (1940) and Senger and Kacy (1952) that the genus Burybelind showed affinities with the Apophallinae. Yamagut1 (1958) amended Euryhelminee to Euryhelminthinae using the following characterIotics: (1) Body wider than long, (2) ritellaria extensively deroloped extending the entire length of the ceca, and (3) a T-shaped excretory vesicle. Brenes and Arroyo (1960) described Euryhelmis costaricensis and suggested a rerision of the genus. They were in agreement with Morozor (1950), supporting the viev that the genus Durihelints should be assigned to the subfardly Euryhelntine Morozor, 1950. Burrhelmis cotti is described in this paper. The anthor is in accord with those placing the genus in Apophallinae. 
Morozor (2950), Yamagut1 (1958) and Brenes and Arroyo (1960) have used characters that are generic and/or specific as having sub-family significance. On the basis of these characters, they argue in favor of the erection of a subfamily to contain the genus Buryhelmts. Yamagut1 (1958) and Brenes and Arroyo (1960) acknowledge the spectes pactificus and pyriformis as being properly placed generically but then appear to ignore them at the subfamily level. 


\section{CONCLUSION}

A new species of the genus Euryhelmis is described in this paper. Its life cycle was partially determined, and data on the distribution of the species in Morthwest Oregon is presented. A partial review of the subfam1ly Apophallinse is presented wth - complete review of the genus Euryhelmis. Original keyo were propared for the genera of the subfamily Apophallinae and for all the described species of Euryhelmis.

The author is in accord with Price (1940), Senger and Macy (1952), and Webster and Wolfgang (1960) that the genus Euryhelmis is properly placed in the subfamily Apophallinae Ciurea 1926.

The argument that the genus Euryhelruls should not be Included with the Apophellinae is considered invalid. The descriptions of Euryhelmis pacificus, pyriformis and cotti clearly indicate a olose relationship with the otber geners of the subfandly. 


\section{BIBLIOCRAPEI}

Mrrica, C. M., and I. Y. Gare1a. 1935. Heterophyid trematodes of anen and dog in The Philippines with descriptions of three new epecier. Philip. J. Sc1. V57(2): 253.

- 1938. Description of three trematodes of the genus Haplorchts (Heterophyldae) with notes on two other Philippine mombers of th1s genue. Philip. J. Sc1. 66: 299-307.

I. I. Garcia and W. DeLeon. 1940. V1sceral complication in intestinal heterophyldiasis of man. III International Congr. Microbtol. (New York Rep. Proc.): 447-449.

1wel, Donald J. 1938. The morphology and Iffe cycle of Euryholmis monorchis n. sp. (trematoda) from the mink. J. Parsisitol. June $24(3)$ : 219-224.

,W.w. Cort and Annie Van der Woude. 1950. Germinal dorelopment in the Heterophid, Euryhelmis monorchis Amel, 1938. J. Parasttol. 36(5): 427

Andersion, Glen A., and Iran Pratt. 1965. Cercarla and Firat intermodiate host of Euryhelmis Equamula. J. Parasitol. 51(1): 13-15.

Babero, B. and J. R. Shepperson, 1956. Som Helminthe of raccoons $\therefore$ in Goorgia. J. Parasitol. 43:519.

Baer, J. C. 1931. Quelques Helminthos rares ou peu connus de Puto1s. Rer. Sulsse Zool, 38: 313-334.

Brenes, Rodrigo Ramon, Guldo Arroyo, and Otto Jimenez-Quiros. 1960. Helmintos de la Republica de Costa Rica IVIII. Una nueva especie de Euryhelmis (Trematode: Heterophy1dae) parasito de Mustela frenata costaricensis, Ror. B1ol. Trop., 8(2): 247-251.

Callot. 1946. Materianx pour servir a la fauna des diatomes de France. Annales de Parasitolog1e Eumaine et comparee, Parls. 21: $199-201$.

Camoron, Thomas W. 1936. Studies on the Heteroph1d Trematode, Apophallus ventrus (Ransom, 1920) in Canada. Part I. Morphology and Taxonomy. Can. J. Res. Sec. D. Vol, 14:59.

- 1937. Studies on the Heterophoid Trematode Tpophallus rentrus (Ransom 1920) in Canada. Can. J. Res. Sec. D. Vol. 15: 38 . 
Dunazan, T. I. 1960. Cercaria belonging to the Cpisthorchoidea. Pro. Helminth. Soc. 27(1): 44 .

Hon, P. I. 1951. A comparative study of the early larval stages of cone heterophyld trematodes belonging to the genera Haplorchis and Procerovin (Trematoda: Heterophyidee). Lingnan. Sc1. J. 23: $235-256$.

Iuntz, R. B. and A. C. Chandlex. 1956. Studies on Egyt1an tromatodes Ith special reference to heterophyids of marmals. I Adult Plukes with the description of Phaglicola longicollis $\mathrm{n}$. sp., Grodiplos tomun namui $n$. ep. and stephanoprora from cats. J. Parasitol. 42:445-459.

Kruidenier, Francis J. 1952. Studies on the formation and function of mucoid glands in cercaria: oplsthorchold cercaria. J. Parasitol. p. 385 .

Iaird, Marshall. 1961. Distomtasis in Tokelau Islandors. Can. J. Zool. $39: 149$.

Lelper, J.W.G. 1936. The occurrence of Molineus patens Dujardin, 1845 in English toats and weasels. J. HeIminth. $14(2): 119-126$.

Lveter, I. 1940. Apophallus Imperator sp. nov,s a hoterophyld encyoted in trout, with a contribution to its life history. Can. J. Res. 18: 106-121.

Yacy, R. W. and D. J. Moore. 1954. On the life cycle and taxonomic relat1ons of Cephaliphallus obscurlus N.G.., n. op., an intestinal trematode (Iecithodendrildae) of mink. J. Parasitol. 40:1-8.

A.K. Berntzen and Mary Benz. 1967. In vitro excystation or Sphaeridiotrema globulus metacercar1ae, structure of cyst, and tho relationship to host specificity. J. Parasitol. 54:28-38.

Mart1n, H.E. 1950. Parasitictodora hancock1 H.G., n. sp. (Trematode: Heterophidae), with observations on its life cycle. J. Parasitol. $36: 360-370$.

and Robert E. Kuntz. 1955. Some Egptian Boterophyid tromatodes. J. Parasitol. $41(4): 374$.

- 1958. The life histories of some Hawailan Heterophyid tromatodes. J. Parasitol. $44(3): 305-323$.

- 1959. Egyptian Heterophyld Trematodes. Trans. Aner. Meroscopial Soc. $75(2): 172$.

HeIntoeh; A. 1936. The occurrence of Euryhelmi squamula in the Untted States. J. Parasitol. 22:536. 
Hiller, M. J. 19l46. The cercarla of Apophallue brevis. Can. J. Res. $24(D 2): 27$.

Parker, M. T. 1950. Buryhelmis squamula (Rudolpht, 1819) reported frow a raccoon. J. Parasitol. $36: 89$.

Price, Bumott, W. 1931. Matagonimoldes oregonensis, a new trematode from a raccoon. J. Wahh. Acad. Se1. 21(16):405.

- 1932. The trematodes parasites of marine mamels. Proc. U.S. Nat. Musenm. 81(13):1-68.

- 1936. A nex heterophyid trenatode of the genus Ascocotyle (Centrocestinae). Proc. Heininth. Soc. of Wash. 3:31-34.

- 1940. A review of the trematode superfamily Oplsthorchiodes. Proc. Holodinth. Soc. Wash. 7(1):1-13.

Ranson, Brayton H. 1920. Synopsis of the trematode family heterophyidae ith descriptions of a new genus and five new species. Proc. 0.S. Nat. Museum. 57 (2322): 527 .

Rayok1, C., and M.A.M. Fahmy. 1962. Investigation on some trematodes of birds from the Bast Scotland. 2.f. Parasitenkunde 22:186-195.

Senger, Clyde M. and Ralph W. Macy. 1952. Helminths of northwest mammale. Part III. The description of Euryhelmis pacificus n. sp., and notes on 1ts lifo cycle. J. Parasito1. $38(5): 481$.

and K.A. Ne1land. 1955. Helminth parasites of somo Fur bearers of Oregon. J. Parasitol. 41: $637-638$.

Stunkard, H. W. and H. C. Willey. 1929. The derelopment of Cryptocotyle (Betorophyidao) in 1 ts final host. Amer. Jour. Trop. hed. 9:117-128.

Webster, Gloria A. and R. W. Wolfgang. 1956. Aleria canadensis op. nov. and Euryhelnds pyriformis sp. nov. Irom the skunk Hephitis pophitis in Quebec. Can. J. 2001. 34:595-601.

W1Iley, Charles H. and Horace W. Stunkard. 19L2. Studies on pathology and resistance in terns and dogs infected with the trematode Cryptocotyle 1ingua. Trans. Amor. Microscopical Soc. 61(3):236.

Witonberg, Q. 1929. Studies on trematode family Heterophyidao. Ann. Trop. Hed. and Parasitol. 23:131-239.

Wong, Lois W. 1954. Bridence of tissue Invasion in chicks by Euhaplorihis californiensis Kartin, 1950 (Trematoda: Heterophyidae). J. ParasitoI. 40(3):316.

Tamagut1, S. 1958. Systema helminthum. The digenetic trematodes of rertebrates. Int. Sei. Pub., Now York. Vol. 1, Parts I and II. 
APPENDIX A

ECPERIIENTAL IHEECTTON OF IABORATORY ANTMALS:

SOLUTIONS AND TECHITUES

EARLE'S SALT SOLUTTON

Component

Iacl

KCI

$\mathrm{IaH}_{2} \mathrm{PQ}_{4} \cdot \mathrm{H}_{2} \mathrm{O}$

$\mathrm{H}_{\mathrm{SOO}} \cdot \mathrm{OH}_{2} \mathrm{O}$

alneose

$\mathrm{CaCl}_{2}$ (anhydrus)

Phenol Red

$\mathrm{AnACO}_{3}$

Stock Solution $20(x)$

Prepare one Iiter by multiplying the quantities by 20 and combining all of the ingredients except the $\mathrm{KaHCO}_{3}$. Dispense into 50 al containers and freeze.

Working Solution

D1lute $50 \mathrm{ml}$ of stock solution to $900 \mathrm{ml}$, add $20 \mathrm{ml} 5$ percent sodiun bicarbonate in dist1lled water and dilute to one 11ter.

0.9 PERCENT SALTIE

Component

Quant1ty

$\mathrm{IeCl}$

$9.0 \mathrm{gm}$

Distllled water 
PEPST SOLUTION (0.5 PERCENT SOLUTION)

Component

Popsin 1: 10,000

Concentrated HCI

0.9 porcent salino
Quantity

$5 \mathrm{gm}$

$5 \mathrm{ml}$

$995 \mathrm{ml}$

The pepein is added to the acid saline solution, and the solution 1o allowed to reach a tomperature of $37^{\circ} \mathrm{C}$ with gentle agitation on a magnetic stirrer for one hour (vigorous agitation would donature the enzyme). Freshly ground fish is then added to the pepsin solution, one gram ground f1sh per 20 mlo pepsin solution. The mixture is maintained at $37^{\circ} \mathrm{C}$ with gentle agitation for one hour. IRIPSII SOLUTION ( 2 PERCENT SOLUTION)

Irypsin - $0.1 \mathrm{gm}$

Earle's alt solution -..--10.0 ml

Idd 5 percent $\mathrm{NaHCO}_{3}$ to the above solution to obtain the dosired $\mathrm{pH}$.

Wotacercarial cysts removed from the pepsin digest are added to the trypsin solution. One may observe the excystment undor elther a dissecting or compound microscope.

Other tochniques of excystation are avallable: (1) One may mochanically disrupt the cyst wall with needles or other suitable devices, and (2) it has been shown that Paragonimas westermani metacercarlae excyst after two bours when placed in warn 0.5 percent to 2.0 percent sodium bicarbonate. Macy (1952) oxcjoted the motacercarize of Cephalophallus obsurus by placing then in 0.1 to 0.5 molar sodiun hydroxide. 
IIFECTION OF LABORATORY ANIMALS

If the experimenter is not experienced in the procedures oxplained below, it would be an excellent idea to carry then out ueine distilled water only on a practice animal. This will enable one to become somewhat proficient without the possible vaste of eyots. Thio is suggested because of the difficulty in obtaining wotecercartal cysts in some casen.

Infoction by pipette

This mothod is fast and relatively easy. The advantages of this technique are: (1) Iinited material needed and (2) no danger of kdlling the animal by over-anesthetizing (anesthetic not used). The disadrantages are: (1) animel may "spit" out the cyst (2) it is generally ineffective in gifing large numbers of cysts at one feeding, and (3) the hendler may be bitten by the animal being fed.

The ejots are first concentrated in the bottom of a Stender dish or a concave slide. They are then washed in distilled water to remove the salt (saline may cause the animal to regurgitate). Mext, the animal to be infected 18 grasped behind the neck and held gently but firmly with one hand, the other hand being used to handle the pipette (care must be made in selecting a pipotte that has no sharp edges). The concentrated cyste are socked into the pipetto and then the pipette is placed about mid-way into the mouth of the enimal (the mouth 1o generally open as the animal is atteupting to nibble the finger tips of the handler), and a drop of the infective ruepention 18 placed in the animal's oral cavity. Care must be taken at this point to make sure that the animal swallows before one 
Introduces another drop of flufd, if the animal has not had timo to owellow, the newly introduced naterial will dribble down his chtn and be wasted. After the administration of the metacercariae, 1t 1s desirable to gire the animal a few drops of fresh water to waih down material that nay be remaining in the wouth.

Infection by Stomach Tube

Use a stomach tube fitted to a needle and attached to a $2.5 \mathrm{mll}$ syringe. For rats, hamstors, and mice, Tygon trubing $15 \mathrm{~cm}$ long and 1 mon wde is used. When feeding mice, the amount of fluid should not oxseed $I \mathrm{ml}$. When introducing the stomach tube into the esophagus, 1madiately withdraw the tube if the animal begine to choke or axibite difficulty in broathing. These symptome indicate that the tube is in the traches. If pressure is encountered when the fluid 1s expelled, do not force the fluid through the tube as this is Indfeative of being in the traches. Withdraw the tube and try again.

\section{AMESTHETIZING SMALL MAMMALS}

When infecting smell laboratory animals, it to ofton convenient to lightly anesthotize then prior to infection to facilitate handling. Place the animal in a jar containing cotton soaked with chloroform or ether. Watch the animal closely, and remove it as soon 20 it becomes disoriented and eleepy. It is important not to allow the andmal to remain in the jar too long as (especially mice and hamsters) they are rapidly affected by the anosthetic. When infecting chicks 1t is adrised not to use an anesthetic as they are extremely susceptible to chloroform and ether. 
APPEIDIX $B$

FIXATTON AND STAINING: SOLOTIONS AND TECHNIQUES

\section{CARMIRE STAINS}

Gronacher'a Alcoholic Borax Carmine

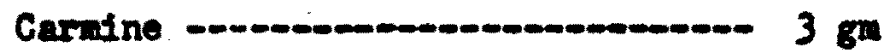

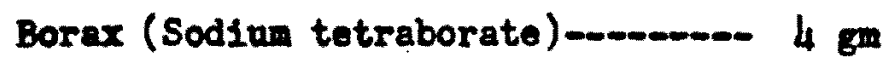

Dist11led vater - $100 \mathrm{ml}$

Boil unt1l the carmine 1s dissolved then add:

70 percent nthanol or ethanol $-100 \mathrm{ml}$

Mlow the solution to stand at roon temperature for several

days then filter 1 .

MYAR'S PARACARMINE

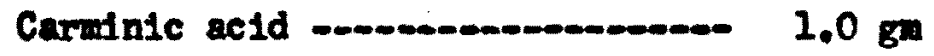

Aluminum ehloride -

Celcium chloride -

1lcohol, 70 percent

Heat the mixture until all the ingredients are diseolved, then I1ter.

\section{SBMTCHON 'S CAPMINE}

Hx equal parts glacial acetic acid and distilled vater. Add poudored carrine until a seturated solution 18 obtained. Place this oolution in a water bath, mintaining the temperature at 95 to $100^{\circ}$ centigrade for fifteen minutes. Cool and lot settle. Decant 
and filter the supernatant.

EMRLTCH'S ACID HEMATOXIIIN

Water -

95 percent ethanol

Hematoxylin -

Glycerine -

Glacial acetic ac1d _........... $10 \mathrm{ml}$

Immonia alum - $20 \mathrm{gm}$

Dissolve the hematoxylin in alcohol, then add ac1d, water and eljcerino in the aforementioned sequence. Mix well, add the alum (aluarinan amoniam sulfate). Allow the solution to ripen in the ounlight for about two months, opening the bottle occasionally.

$\operatorname{BOSTI}$ (STOCR)

Eosin powder - $2 \mathrm{gm}$

95 percent methanol - $200 \mathrm{ml}$

Dilute 1:10 in 95 percent methanol before using.

PAST GREQT

Fast green Bolution (1 percent)-- $\quad 1 \mathrm{ml}$

95 percent ethanol -............ $49 \mathrm{ml}$

\section{OIISON'S FIXATIVE}

Dist1lled water …_..._._._._. $220 \mathrm{ml}$

70 percent ethanol _..._......... $25 \mathrm{ml}$

80 percent nitric acid _............. 4 ml

Glecial acetic acid -............ $1 \mathrm{ml}$

Mereuric chloride -...-..-.... 5 gm 
TECHNTQUES OF FIXATION AND STATNING

Whole Kounts

Place one fluke on a glass slide in a drop or two of 0.9 percent saline. Place a cover slide over the animal and observe under a dissecting microscope. When it appears that the animal is somewhat relaxed, place a plece of lons paper against the air water interface eimeltaneously placing a drop of Gilson's on the opposite side of the cover alip. Capillary action will draw off the saline replacing 1t with Gilson's. Movement will cesse, and the animal will take on a dark color, when this occurs remove the lene paper and lot the slide sot for fifteen minutes. Place a drop of Gilson's near the cover slip, floating it then lift the cover slip off the fluke. Hext float the animal from the surface of the slide. This can be done by holding the cover slip at about $85^{\circ}$ to the surface of the slide and gently nudging the fluke unt1l it no longer adheres to the slide, then squirt fixative on 1t, washing it from the slide into a Stonder dish containing oflson's. Then proceed as follows:

(1) 01180n's 12 hours to overnight

(2) 35 percent othanol 30 minutes each

(3) 50 percent thanol 30 minutes each

(4) 70 percent ethanol 30 minutes each

(5) 70 percent othanol 2 hours to orernight

(6) 70 percent ethanol 30 minutes each

(7) 70 percent othanol 30 mdnutes each

(8) 50 percent ethanol 30 minutes each

(9) 35 percent othanol 30 minutes each 
(10) Bhrilch's Bematorglin

overnight

(II) 35 percent othenol

30 minutes

(12) 50 percent ethanol

30 minutes

(13) 70 percent ethanol

30 minutes

(山) destain *

(15) 80 percent ethanol

30 minutes

(16) 95 percent othanol

30 minutes

(17) counterstain (fast green)

10 to 20 seconds

(18) 95 percent othanol

25 minutes

(19) 100 percent 18opropyl

60 minutes

(20) solene

30 minutes

Nount in belsan, place slides in oren with the temperature maintained at about 37 to $50^{\circ}$ contigrade for several days to one week. If ono wishes to exploy a carmine etain, place the animals at stop (7) in the carmine stain and allow then to remain overnight, then wash in 70 percent ethanol and destain and go to step (15) following the Flow sheet to 1 ts concluston.

* Plece one to several flukes in Stender d1sh containing 70 percent ethanol, then add a drop of atrong destain, observing the Fuke(a) under a dissecting microscope. When the stain appears to be of the desired intensity, remove the flukes from the solution, placing them in fresh 70 percent ethanol.

\section{Sections}

Nukes to be sectioned are not Nlattened. Place I1ving Nukes In a Stonder dish containing oilson's fixative and allow then to rosain in the fixative overnight, then dehydrate as follows: 
(1) 30 percent thanol

30 minutes

(2) 50 percent ethanol 30 minutes

(3) 70 percent othanol 30 minates

(4) 70 percent othanol orernight

(5) 70 percent ethanol 30 winutes

(6) 70 percent ethanol 30 minutes

(7) 80 percent ethanol 30 minutes (8) 95 percent ethanol 30 minutes (tint snall flukes by adding small amount of cosin to the 95\%) (9) 100 percent isopropyl at least 2 hours Then proceed wth dealcoholization (keep containers tightly covered) (1) 1 part tolueno, 3 parte 100 percent 18opropyl alcohol- 30 minutes (2) 1 part toluene, 1 part 100 percent 1sopropyl alcohol -- 30 minutes (3) 3 parte toluene, 1 part 100 percent 18opropyl alcohol - 30 winutes (4) 100 percent toluene (Change to fresh toluene once in this period). The next otep is to infiltrate ifth paraffin. For material that is to be merotoned Into sections of 12 mera or less, hard paraffin is need. The welting point of hard paraffin in $56^{\circ}$ centigrade. The oven to matntained at $57^{\circ}$ centigrade. Keep a supply of melted paraffin in the oven. Preliminary infiltration is as follows: (1) Remove toluene, cover the material with warm mixture of 1 part molted paraffin and 3 parts tolveno. Leave this uncovered in oven for 30 minutes.

(2) Place flukes in 1 part paraffin and 1 part toluene for 30 minutes. (3) 3 parts paraffin, 1 part toluene for 30 mimutes. 
(4) Place flukes in pure paraffin, changing to fresh paraffin every

20 unutes for 3 changes.

(5) Bubed and cut ribbon.

(6) Me1x to slide.

Treat slides as follows:

(1) Xylene

2 minutes

(2) Iylene + 100 percent 1sopropyl alcohol -- 2 minutes

(3) 100 percent 18opropyl alcohol

2 minutes

(4) 95 percent ethenol

2 minutes

(5) 80 percent othanol

2 minutes

(6) 70 percent othanol

2 minutes

(7) 50 porcent othanol

2 minutee

(8) 35 percent othanol

2 minutes

(9) Water

2 minutes

(10) Stain with iron hematoxylin

approximately 20 minutes

(11) Water 10 minutes

(12) 35 percent ethanol

2 minutes

(13) 50 percent ethanol

2 minutes

(I4) 70 percent othanol

2 minutes

(15) 80 percent ethanol

2 minutes

(16). 95 percent othanol

2 minutes

(17) Bosin approximately 30 seconds

(18) 100 percent 18opropyl alcohol 2 ainutes

(19) 100 percent isopropyl alcobol+kglene o- 2 minutes

(20) xyleno 2 inutes

Mount in balsam. 